\title{
SONARAVNE USMERITVE PRIHODNJEGA PROSTORSKEGA RAZVOJA LJUBLJANE
}

\author{
Dušan Plut \\ Oddelek za geografijo Filozofske fakultete Univerze v Ljubljani, Aškerčeva cesta 2, \\ SI - 1000 Ljubljana, Slovenija \\ e-mail: dušan_plut@t-2.net
}

Izvirni znanstveni članek

COBISS 1.01

\section{Izvleček}

V Mestni občini Ljubljana (MOL) je varstvo okolja eno izmed treh temeljnih (gospodarsko in socialno polje), a neenakovredno obravnavanih polj sonaravnega, trajnostnega mestnega razvoja. Čeprav se Ljubljana med evropskimi mesti podobne velikosti ne uvršča med najbolj degradirana urbana območja, predstavljajo okoljski problemi zaradi številnih posledic na kakovost bivanja in izčrpavanje naravnih virov, ogrožanja narave, enega od ključnih problemov. Zaščita talne vode Ljubljanskega polja, umiritev suburbanizacijskih procesov in cestnega prometa ter prostorski razvoj v okviru omejitev okolja so temeljni sonaravni prostorski izzivi mestnih politik Ljubljane in MOL.

Ključne besede: prostorski razvoj, sonaravni razvoj, varstvo okolja, Ljubljana

\section{SUSTAINABLE DIRECTIVES OF FUTURE SPATIAL DEVELOPMENT OF LJUBLJANA}

\begin{abstract}
Environmental protection in the Ljubljana city municipality is one of three basic (beside economic and social), but unequally treated spheres of sustainable urban development. Compared to other European cities of similar size, Ljubljana is not supposed to be among the most degraded urban areas. However, with some additions, the Spatial plan of the Ljubljana city municipality is a suitable expert scheme for more environmentally adjusted spatial development. Essential sustainable spatial challenges of cities policies in Ljubljana and Ljubljana city municipality are to protect the underground water of Ljubljansko polje, to calm down the suburbanization processes and road transport within the environmental limits.
\end{abstract}

Key words: spatial development, sustainable development, environmental protection, Ljubljana 


\section{METODOLOŠKA ZASNOVA}

Ljubljano in celotno Mestno občino Ljubljana prostorsko in okoljsko temeljno označuje geografska lega $\mathrm{v}$ večji in gosto naseljeni predalpski kotlini, večja občutljivost nekaterih sestavin okolja, ugodna prometna lega in naraščanje prometnih pritiskov, zgostitev različnih dejavnosti, prostorsko širjenje. Ključni razvojni programi in projekti naj bi torej omogočili prihodnji razvoj Ljubljane v smeri tekmujočega in trajnostno sonaravnega državnega središča srednje Evrope v razširjeni Evropi (Pichler Milanović, 2005, s. 356):

- $\quad$ izboljšanje prometne infrastrukture-prenova železniških in avtobusnih postaj, javni promet, parkirne hiše itd.;

- $\quad$ povečanje nizke bivalne urbane gostote;

- $\quad$ izboljšanje gospodarjenja z odpadki;

- nove rekreacijske površine.

Osnovni namen prispevka je okoljska analiza in okoljevarstveno zasnovana presoja preteklih in prihodnjih prostorskih politik MOL-a v obdobju 1990-2015 z vidika možnosti in omejitev udejanjanja sonaravnega urbanega razvoja. Delovna hipoteza izhaja iz predpostavke, da so okoljski problemi tudi posledica preteklega prostorskega razvoja, načrtovani prostorski razvoj MOL pa naj bi pomembno vplival na obseg in intenzivnost degradacijskih procesov.

Za okvirni prikaz okoljevarstvenih razsežnosti prostorskega razvoja MOL smo uporabili prilagojen metodološki model DPSIR Evropske agencije za okolje, ki izhaja iz analize stanja okolja, negativnih vplivov zmanjšane kakovosti bivalnega okolja in njegovih pokrajinotvornih sestavin, izluščenja temeljnih gonilnih sil okoljskih pritiskov, pokrajinske obremenjenosti in občutljivosti ter predlogov za prostorskim in okoljskim omejitvam prilagojen, sonaravni prostorski in gospodarski razvoj (Environment in the European Union..., 1999). Glede na delovno hipotezo o vključevanju okoljskih vsebin v sonaravno zasnovano prostorsko načrtovanje Mestne občine Ljubljana (MOL) pa je z geografskega in prostorskega vidika smiselno preoblikovanje osnovnega metodološkega modela v naslednje sklope (Preglednica 1) :

- $\quad$ kakovost okolja: stanje in trendi v okolju oziroma sestavinah okolja;

- $\quad$ vplivi kakovosti okolja (posledice);

- občutljivost okolja na obremenjevanje - samočistilne (nevtralizacijske in regeneracijske)

- zmogljivosti sestavin okolja;

- $\quad$ pritiski na okolje (obremenjevanje okolja) in viri (ključne gonilne sile) pritiskov na okolje;

- okoljska ocena preteklega prostorskega razvoja in predlogi sonaravno zasnovanih ukrepov prihodnje prostorske politike.

Za sintezno primerjalno okoljsko oceno preteklega in prihodnjega prostorskega razvoja in ocene vpliva na okolje z vidika prihodnjega prostorskega razvoja Mestne občine Ljubljana (2006-2015) glede na izdelano Prostorsko zasnovo MOL (2002) je bila izdelana dvoplastna matrična metodološka zasnova (Preglednica 2). 
Preglednica 1: Integralni geografski model okoljevarstvenega raziskovanja prostorskega razvoja Mestne občine Ljubljana (1990-2015)

Table 1: An integral geographic model of the researching of the spatial development of the Ljubljana Municipality from the perspective of environmental protection (1990-2015)

\begin{tabular}{|c|c|c|c|c|}
\hline $\begin{array}{l}\text { 1. Stanje in trendi } \\
\text { kakovosti okolja }\end{array}$ & $\begin{array}{l}\text { 2. Vplivi kakovosti } \\
\text { okolja }\end{array}$ & $\begin{array}{l}\text { 3. Občutljivost } \\
\text { okolja }\end{array}$ & $\begin{array}{l}\text { 4. Pritiski na } \\
\text { okolje }\end{array}$ & $\begin{array}{l}\text { 5. Viri pritiskov } \\
\text { na okolje }\end{array}$ \\
\hline $\begin{array}{l}\text { 1.1 Degradacija } \\
\text { sestavin okolja, } \\
\text { naravnih virov } \\
\text { Onesnaženost zraka } \\
\text { Hrup } \\
\text { Onesnaženost vodnih } \\
\text { virov (vodni tokovi, } \\
\text { talna voda) } \\
\text { Degradacija prsti } \\
\text { Degradacija vegetacije } \\
\text { 1.2 Degradacija } \\
\text { (razvrednotenje) } \\
\text { prostora, pokrajine } \\
\text { Degradirana urbana, } \\
\text { industrijska in druga } \\
\text { območja } \\
\text { Naravna in kulturna } \\
\text { pokrajina z zmanjšano } \\
\text { ekosistemsko in } \\
\text { pejsažno vrednostjo- } \\
\text { regulacije vodotokov, } \\
\text { odlagališča odpadkov } \\
\text { 1.3 Splošna oznaka } \\
\text { stanja in trendov } \\
\text { kakovosti okolja, } \\
\text { prostora, degradacijska } \\
\text { tipologija }\end{array}$ & $\begin{array}{l}2.1 \text { Bivalno okolje } \\
\text { (zlasti zdravje } \\
\text { in počutje) } \\
2.2 \text { Naravni viri } \\
\text { (za kmetijsko } \\
\text { rabo, poselitev, } \\
\text { turizem, vodno } \\
\text { oskrbo, obnovljivi } \\
\text { - neobnovljivi; } \\
\text { prostor kot naravni vir) } \\
\text { 2.3 Narava, pokrajina } \\
\text { (zmanjšana stabilnost } \\
\text { ekosistemov, } \\
\text { zmanjšanje biotske } \\
\text { raznovrstnosti, } \\
\text { negativni vplivi na } \\
\text { zavarovana območja } \\
\text { itd.) } \\
\text { 2.4 Ocena } \\
\text { součinkovanja vplivov } \\
\text { na kakovost mestnih } \\
\text { območij }\end{array}$ & $\begin{array}{l}\text { 3.1 Občutljivost } \\
\text { zraka (ozračja) } \\
3.2 \text { Občutljivost } \\
\text { voda - vodni tokovi, } \\
\text { talna voda } \\
\text { 3.3 Občutljivost } \\
\text { drugih sestavin } \\
\text { okolja } \\
\text { 3.4 Občutljivost } \\
\text { okolja na naravne } \\
\text { nesreče } \\
\text { 3.5 Naravovar- } \\
\text { stveno vrednotenje } \\
\text { habitatnih tipov } \\
\text { 3.6 Tipologija } \\
\text { območij z vidika } \\
\text { občutljivosti okolja }\end{array}$ & $\begin{array}{l}\text { 4.1 Snovni in } \\
\text { energetski tokovi } \\
4.2 \text { Emisije plinov } \\
4.3 \text { Emisije hrupa } \\
4.4 \text { Odpadne vode } \\
4.5 \text { Odpadki } \\
\text { (količine in } \\
\text { sestava) } \\
4.6 \text { Spremembe } \\
\text { rabe prostora } \\
\text { (z vidika pritiskov } \\
\text { in občutljivosti } \\
\text { okolja) } \\
4.7 \text { Ekološki odtis }\end{array}$ & $\begin{array}{l}\text { 5.1 Poselitev } \\
5.2 \text { Industrija } \\
5.3 \text { Energetika } \\
\text { 5.4 Promet } \\
\text { 5.5 Trgovina in } \\
\text { druge storitve } \\
\text { 5.6 Kmetijstvo } \\
5.7 \text { Rekreacija s } \\
\text { turizmom } \\
\text { 5.8 Regionalni } \\
\text { (zunanji) viri } \\
\text { pritiskov na okolje }\end{array}$ \\
\hline $\begin{array}{l}6.1 \text { Okoljska ocena } \\
\text { dosedanjega in predlog } \\
\text { okoljevarstvenih } \\
\text { smernic ter ukrepov } \\
\text { prihodnje prostorske } \\
\text { politike }\end{array}$ & $\begin{array}{l}6.2 \text { Okoljska ocena } \\
\text { dosedanjega in predlog } \\
\text { okoljevarstvenih } \\
\text { smernic ter ukrepov } \\
\text { prihodnje prostorske } \\
\text { politike }\end{array}$ & $\begin{array}{l}6.3 \text { Okoljska } \\
\text { ocena dosedanjega } \\
\text { in predlog } \\
\text { okoljevarstvenih } \\
\text { smernic ter ukrepov } \\
\text { prihodnje prostorske } \\
\text { politike }\end{array}$ & $\begin{array}{l}6.4 \text { Okoljska } \\
\text { ocena dosedanjega } \\
\text { in predlog } \\
\text { okoljevarstvenih } \\
\text { smernic ter } \\
\text { ukrepov prihodnje } \\
\text { prostorske politike }\end{array}$ & $\begin{array}{l}6.5 \text { Okoljska } \\
\text { ocena dosedanjega } \\
\text { in predlog } \\
\text { okoljevarstvenih } \\
\text { smernic ter } \\
\text { ukrepov prihodnje } \\
\text { prostorske politike }\end{array}$ \\
\hline
\end{tabular}


Preglednica 2: Matrična zasnova ocene vpliva na okolje z vidika prihodnjega prostorskega razvoja Mestne občine Ljubljana (2006-2015)

Table 2: A matrix scheme of the estimate of the influence on the environment from the perspective of further spatial development of the Municipality of Ljubljana (2006-2015)

\begin{tabular}{|c|c|c|}
\hline $\begin{array}{l}\text { Olje za vrednotenje okoljskega } \\
\text { vpliva }\end{array}$ & Razredi za vrednotenje okoljskega vpliva & $\begin{array}{l}\text { Oznaka ocene } \\
\text { pretekl. in prihod. } \\
\text { okoljskega vpliva }\end{array}$ \\
\hline A) Stopnja poznavanja, raziskanosti & $\begin{array}{l}\text { 1. ni raziskan } \\
\text { 2. enkratne ali občasne, vzorčne raziskave } \\
\text { 3. občasne sistematične raziskave } \\
\text { 4. stalne raziskave na posamezni lokaciji } \\
\text { 5. stalne raziskave na več lokacijah }\end{array}$ & A $1-5 /$ \\
\hline B) Stanje sestavine okolja & $\begin{array}{l}\text { 1. zanemarljiva degradacija } \\
\text { 2. majhna degradacija } \\
\text { 3. zmerna degradacija } \\
\text { 4. velika degradacija } \\
\text { 5. zelo velika degradacija }\end{array}$ & B $1-5 /$ B $1-5$ \\
\hline C) Trend stanja sestavine okolja & $\begin{array}{l}\text { 1. bistveno izboljšanje } \\
\text { 2. izboljšanje } \\
\text { 3. praktično nespremenjeno stanje } \\
\text { 4. poslabšanje stanja } \\
\text { 5. bistveno poslabšanje stanja }\end{array}$ & C $1-5 /$ C $1-5$ \\
\hline D) Stanje prostorske razširjenosti & $\begin{array}{l}\text { 1. manjše območje, krajši ožji pas (pod } 50 \mathrm{~m} \text { širine) } \\
\text { 2. večje območje }(10-100 \mathrm{ha}) \\
\text { 3. manjše število manjših območij, več ožjih pasov } \\
\text { (pod } 50 \mathrm{~m} \text { ) ali daljši (nad } 1 \mathrm{~km} \text { ) in širši pas (nad } 50 \mathrm{~m}) \\
\text { 4. veliko območje }\left(\text { nekaj } \mathrm{km}^{2}\right) \text {, množica manjših } \\
\text { območij, več daljših ožjih pasov } \\
\text { 5. zelo veliko območje }\left(\text { nad } 10 \mathrm{~km}^{2}\right) \text {, več širokih pasov }\end{array}$ & D 1-5/D 1-5 \\
\hline E) Trend prostorske razširjenosti & $\begin{array}{l}\text { 1. bistveno zmanjšanje } \\
\text { 2. zmanjšanje } \\
\text { 3. praktično nespremenjen } \\
\text { 4. povečanje } \\
\text { 5. bistveno povečanje }\end{array}$ & E 1-5/E 1-5 \\
\hline $\begin{array}{l}\text { F) Intenzivnost posledic - vplivi } \\
\text { onesnaženosti, degradacije okolja na: } \\
\text { a) bivalno okolje } \\
\text { b) naravne vire } \\
\text { c) naravo, pokrajino } \\
\text { d) samočistilne zmogljivosti }\end{array}$ & $\begin{array}{l}\text { 1. zanemarljiva, skromna } \\
\text { 2. majhna } \\
\text { 3. zmerna } \\
\text { 4. velika } \\
\text { 5. zelo velika }\end{array}$ & $\begin{array}{l}\text { Fa } 1-5 / 1-5 \\
\text { Fb } 1-5 / 1-5 \\
\text { Fc } 1-5 / 1-5 \\
\text { Fd } 1-5 / 1-5\end{array}$ \\
\hline G) Pritiski na okolje & $\begin{array}{l}\text { 1. snovni in energetski tokovi } \\
\text { 2. emisije v ozračje } \\
\text { 3. emisije hrupa } \\
\text { 4. odpadne vode } \\
\text { 5. spremembe v rabi prostora }\end{array}$ & $\begin{array}{l}\mathrm{G} 1,2,3,4,5 / \\
1,2,3,4,5\end{array}$ \\
\hline $\begin{array}{l}\text { H) Viri (gonilne sile) degradacije, } \\
\text { pritiskov na okolje }\end{array}$ & $\begin{array}{l}\text { 1. poselitev } \\
\text { 2. industrija } \\
\text { 3. energetika } \\
\text { 4. promet } \\
\text { 5. trgovine in druge storitve } \\
\text { 6. kmetijstvo } \\
\text { 7. rekreacija s turizmom } \\
\text { 8. odlagališče odpadkov } \\
\text { 9. regionalni (zunanji) viri }\end{array}$ & $\begin{array}{l}\mathrm{H} 1,2,3,4,5, \\
6,7,8,9 / \\
1,2,3,4,5,6 \\
7,8,9\end{array}$ \\
\hline
\end{tabular}




\begin{tabular}{|l|l|l|}
\hline I) Ocena preteklega in pričakovanega & 1. zanemarljiva & I 1-5/1-5 \\
vpliva načrtovanega prostorskega & 2. majhna & \\
razvoja na obseg in stopnjo obravnavane & 3. zmerna & \\
degradacije okolja & $\begin{array}{l}\text { 4. velika } \\
\text { 5. zelo velika }\end{array}$ & \\
\hline J) Okoljska ocena preteklega in & 1. pomemben vpliv na zmanjšanje & \\
načrtovanih ukrepov prostorskega razvoja & obremenjevanja, ogroženosti & I 1-5/1-5 \\
z vidika zmanjšanja oziroma povečanja & 2. vpliv na zmanjšanje obremenjevanja, & \\
obravnavane degradacije okolja & ogroženosti & \\
& 3. praktično brez vpliva & \\
& 4. vpliv na povečanje obremenjevnja, ogroženosti & \\
& 5. pomemben vpliv na povečanje obremenjevanja, & \\
\hline K) Ocena konkretne, z vidika & ogroženosti & Ocena, možni \\
obravnavane degradacije okolja okoljsko & 1. & alternativni predlog \\
sporne prostorske zasnove & 2. & \\
\hline
\end{tabular}

\section{KLJUČNI OKOLJSKI PROBLEMI MESTNE OBČINE LJUBLJANA V OBDOBJU 1990-2005}

VMestni občini Ljubljana(MOL)je varstvo okolja eno izmed treh temeljnih(gospodarsko in socialno polje), a neenakovredno obravnavanih polj sonaravnega, trajnostnega mestnega razvoja. Čeprav se Ljubljana med evropskimi mesti podobne velikosti ne uvršča med najbolj degradirana urbana območja, predstavljajo okoljski problemi enega od ključnih problemov (Plut, 2000; 2002, Špes in drugi, 2002; Plut in drugi, 2006).

Kotlinska lega, slabša prevetrenost, ekosistemski pomen Ljubljanskega barja, vodnooskrbna regionalna vloga talne vode Ljubljanskega polja, večja reliefna energija vzhodnega obrobja MOL, potresnost in poplave so temeljne naravne omejitve prostorskega razvoja Ljubljane in omejenih samočistilnih zmogljivosti. Manjše samočistilne zmogljivosti južnega dela Ljubljanske kotline in razmeroma velika obremenjenost pokrajinotvornih sestavin prav tako občutljivega Ljubljanskega polja temeljno vplivajo na veliko ranljivost geografskega okolja Ljubljane in celotne MOL. Ohranjanje ključnih prezračevalnih koridorjev iz obrobja proti središču je za kotlinsko Ljubljano zelo pomembno (Slika 1) (Jernej, 2000). Prav tako je pomembno ohranjanje kakovostnega, rekreacijsko privlačnega vzpetega mestnega obrobja.

Okoljska analiza preteklega in trenutnega stanja ter trendov za obdobje 1990-2005 izpostavlja prostorsko naslednje najbolj relevantne okoljske probleme Ljubljane in celotne MOL:

- $\quad$ naraščanje prometnih emisij (dušikovi oksidi, benzen) ter visoke ravni hrupa $\mathrm{v}$ številnih območjih mestnega jedra, ob glavnih mestnih vpadnicah ter mestni avtocestni obvoznici;

- $\quad$ prekomerna onesnaženost številnih mestnih površinskih vodnih virov in občasna prekomerna vsebnost zdravju nevarnih snovi v talni vodi Ljubljanskega polja (Slika 2);

- $\quad$ naraščanje okoljskih pritiskov na hidrogeografska zaledja črpališč pitne vode, zlasti na Ljubljanskem polju (Kladnik in drugi, 2005);

- $\quad$ velike količine odpadkov, problemi njihovega odlaganja in ponovne uporabe ter veliko število nedovoljenih odlagališč odpadkov; 
Slika 1: Zračni tokovi MO Ljubljana

Figure 1: Air currents of the Municipality of Ljubljana

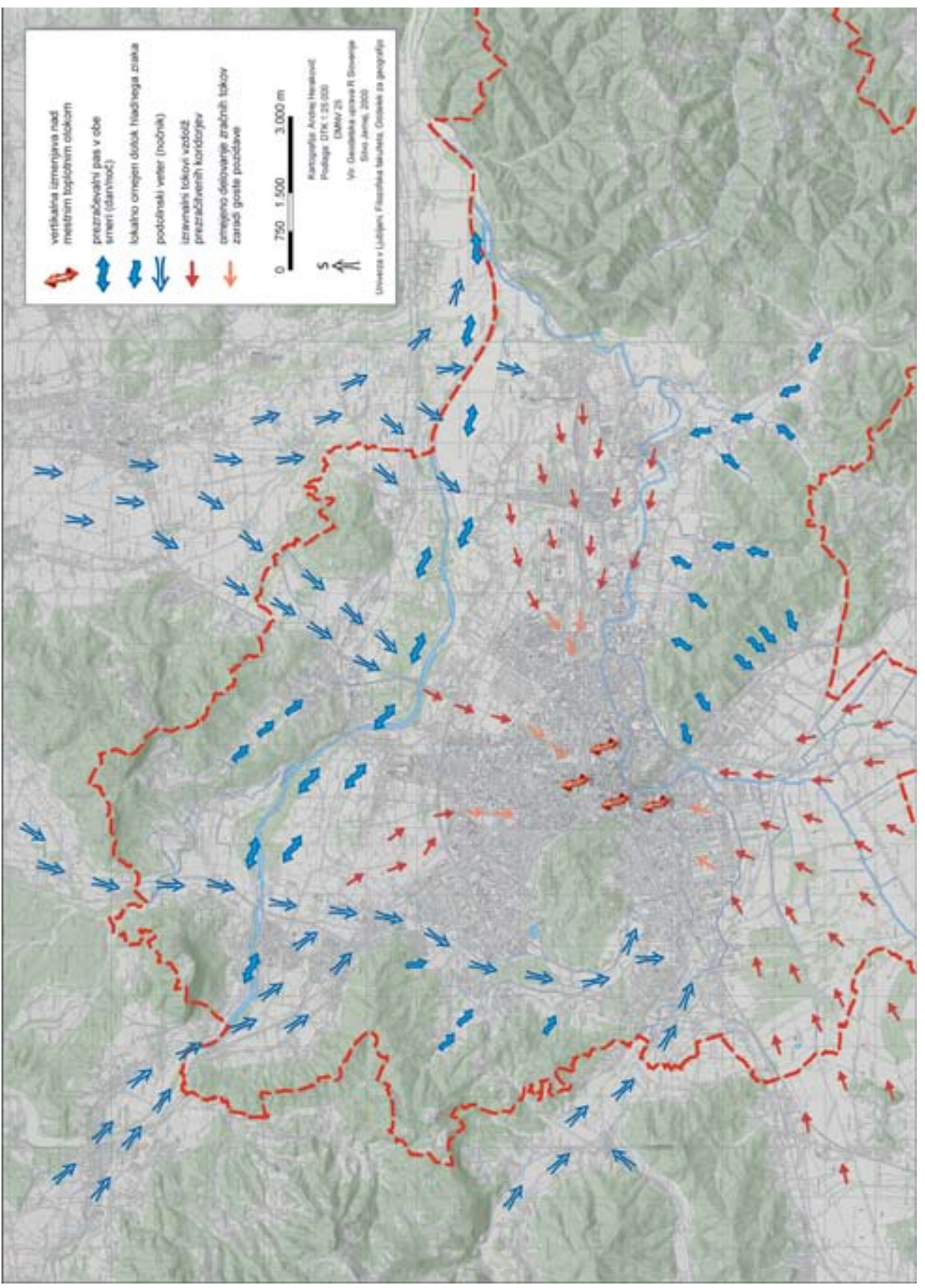


Slika 2: Kakovost vodnih virov Ljubljane (1997-2004)

Figure 2: The quality of the water sources of Ljubljana (1997-2004)

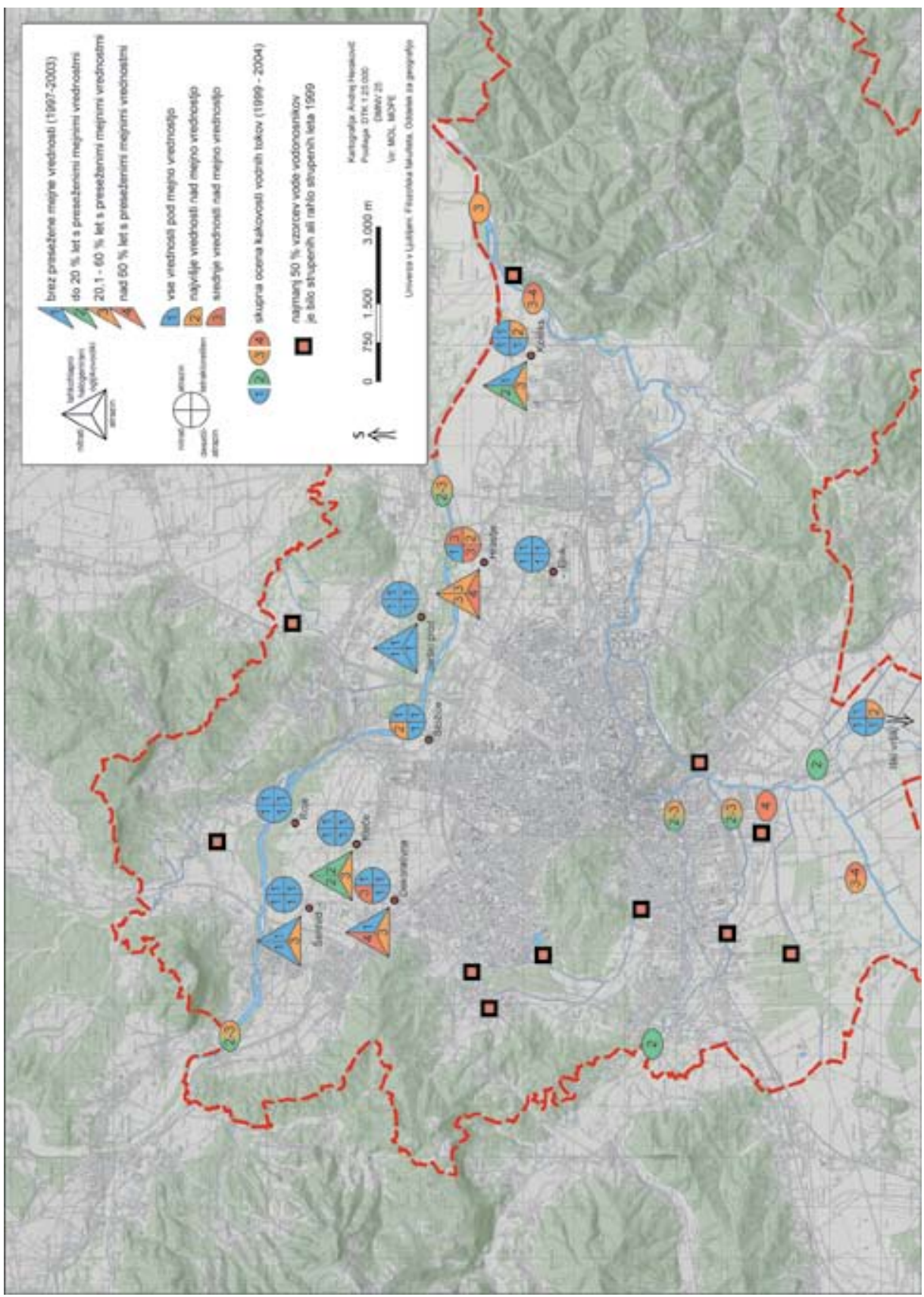


- $\quad$ velike ekološke sledi (odtisi) na prebivalca (kazalec velike porabe naravnih virov in velike količine emisij) ter prekomerne emisije toplogrednega ogljikovega dioksida.

Rangiranje ključnih okoljskih problemov na ravni MOL v obdobju 1990-2005 je bilo opravljeno na osnovi vrednotenja obsega, stopnje in trendov (glede sprememb kakovosti in obsega sestavine okolja) ter intenzivnosti posledic. $\mathrm{V}$ prvi rang na ravni pomena $\mathrm{z}$ vidika MOL so bili torej razvrščeni tisti okoljski problemi, kjer je bila ugotovljena prekomerna onesnaženost $\mathrm{v}$ večjem obsegu, $\mathrm{z}$ izrazito negativnimi posledicami za bivalno okolje, naravne vire, naravo ali na samočistilne zmogljivosti ozemlja MOL. V četrti rang pa so bili uvrščeni okoljski problemi, ki so prisotni lokalno, z manjšimi negativnimi okoljskimi oziroma zdravstvenimi posledicami.

Po mnenju Mušiča (1999) so ključna nerešena vprašanja okolja Ljubljane promet, čiščenje odpadnih vod in problematika odpadkov. Naraščajo zlasti cestno prometni in suburbanizacijski okoljski pritiski. Za Ljubljano je značilno bivalno in ekosistemsko na splošno ugodno razmerje med odprtim prostorom ter pozidanimi površinami. Posebnost mestne zgradbe Ljubljane je prisotnost velikih površin pretežno naravnega okolja (v obliki klinov) praktično v samem mestnem središču. Opozoriti pa je potrebno na relativnost ugodnosti navedenega razmerja, saj je v središču mesta in v bližini nekaterih blokovskih sosesk majhen obseg javnih zelenih površin, zelo skromna splošna gozdnatost mestnega območja, gozdne zaplate so praviloma razdrobljene in majhne.

Z vidika prostorskega razvoja v obdobju 1990-2005 in izvedene okoljske presoje z vidika MOL (torej z občinskega vidika) so bili okoljski problemi razvřšceni v naslednje range (Plut in drugi, 2006):

I. rang: hrup, ogroženost biosfere, dušikovi oksidi (NO) , degradacija manjših vodnih tokov in degradacija prsti;

II. rang: ozon $\left(O_{3}\right)$, onesnaženost talne vode Ljubljanskega polja in nedovoljena odlagališča odpadkov;

III. rang: onesnaženost Ljubljanice, odlagališče Barje in trdni delci;

IV. rang: žveplov dioksid $\left(\mathrm{SO}_{2}\right)$, onesnaženost Save.

Okoljski problemi, ki se pojavljajo na ozemlju MOL in vplivajo na širšo regijo, so bili za obdobje 1990-2005 razvrščeni v naslednje regionalne range:

1. rang: odlagališča Barje, onesnaženost Save, onesnaženost Ljubljanice in onesnaženost talne vode Ljubljanskega polja;

2. rang: dusikovi oksidi $\left(\mathrm{NO}_{X}\right)$ in ozon $\left(\mathrm{O}_{3}\right)$

3. rang: žveplov dioksid $\left(\mathrm{SO}_{2}\right)$, trdni delci, degradacija manjših vodnih tokov in ogroženost biosfere (pozidava pomembnih habitatov, razparceliranje biotopov itd.);

4. rang: hrup, degradacija prsti in nedovoljena odlagališča odpadkov.

Problematika odlagališča Barja je v prvi rang na regionalnem polju uvrščena zaradi dejstva, ker na odlagališča prihajajo tudi odpadki s širše regije. Onesnaženost talne vode Ljubljanskega polja pa je v prvi regionalni rang uvrščeno zato, ker se za kritje potreb po kakovostni pitni vodi prebivalcev MOL uporablja tudi pitna vode izven ozemlja MOL (črpališče Brest). 
V obdobju 1990-2005 se je kakovost okolja v MOL izboljšala zgolj pri dveh oblikah onesnaževanja okolja in sicer pri onesnaženosti z $\mathrm{SO}_{2}$ in delno tudi na zaradi delne sanacije na odlagališču Barje. Stanje okolja je ostalo praktično nespremenjeno pri onesnaževanju z ozonom, trdnimi delci, onesnaženosti Ljubljanice, talne vode Ljubljanskega polja in degradaciji prsti. Poslabšanje stanje okolja pa je bilo prisotno pri onesnaženosti z $\mathrm{NO}_{\mathrm{X}}$, manjšimi vodnimi tokovi, nedovoljenimi odlagališči odpadkov in ogroženosti biosfere. Izrazito poslabšanje stanja pa je bilo prisotno pri mestnemu hrupu.

Lahko zaključimo, da se je v obdobju 1990-2005 kljub nekaterim pozitivnim premikom kakovost oziroma stanje okolja na splošno poslabšalo zaradi naraščanja nekaterih okoljskih pritiskov. Pri trendih prostorske razširjenosti se je obseg območja onesnaženosti v obdobju 19902005 zmanjšal zgolj pri območjih prekomerne onesnaženosti z $\mathrm{SO}_{2}$, praktično nespremenjen pa je ostal obseg pri onesnaženosti z $\mathrm{O}_{3}$, trdnimi delci, onesnaženosti Save, Ljubljanice in talne vode Ljubljanskega polja. Manjše povečanje obsega prekomerne onesnaženosti je bilo prisotno pri $\mathrm{NO}_{\mathrm{X}}$, manjšimi vodnimi tokovi in degradaciji prsti, bistveno povečanje obsega pa pri hrupu, površini odlagališča Barje, nedovoljenih odlagališčih odpadkov in ogroženosti biosfere. Vobdobju 1990-2005 se je na ozemlju MOL v večini primerov stanje sestavin okolja poslabšalo ali ostalo na približno enaki ravni (poziotivna izjema $\mathrm{SO}_{2}$ in odlagališče Barje), prav tako pa se je v večini obravnavanih okoljskih problemov povečal obseg obravnavanih oblik onesnaževanja.

Naraščajo zlasti cestno prometni in suburbanizacijski okoljski pritiski, prostorsko širjenje pozidave. Za Ljubljano je značilno bivalno in ekosistemsko na splošno ugodno razmerje med odprtim prostorom ter pozidanimi površinami. Posebnost mestne zgradbe Ljubljane je prisotnost velikih površin pretežno naravnega okolja (v obliki ti. zelenih klinov) praktično do mestnega središča. Opozoriti pa je potrebno na relativnost ugodnosti navedenega razmerja, saj je v središču mesta in v bližini nekaterih blokovskih sosesk majhen obseg javnih zelenih površin, zelo skromna splošna gozdnatost mestnega območja, gozdne zaplate pa so praviloma razdrobljene in majhne.

$\mathrm{Z}$ vidika načrtovanja sonaravnega prostorskega razvoja Ljubljane so temeljni naslednji okoljski pritiski: naraščanje cestnega mestnega prometa, osebne potrošnje in s tem povezanih komunalnih odpadkov, pozidava območja talne vode Ljubljanskega polja in pretežno stihijski suburbanizacijski procesi, zlasti na ekosistemsko zelo pomembnem Ljubljanskem barju. Intenzivna pokrajinska raba, širjenje pozidanih površin, pretežno razpršena ali delno strnjena suburbanizacija, prepustna kanalizacija, nakupovalna središča izven strnnjenega mestnega prostora, skladišča, mestne obvoznice in s tem povezana večja gostota prometa na Ljubljanskem polju povečujejo okoljsko tveganje varne in zdrave oskrbe Ljubljane s pitno vodo.

\section{SONARAVNE USMERITVE IN PREDLOGI ZA NAČRTOVANJE PROSTORSKEGA RAZVOJA LJUBLJANE DO LETA 2015}

Usmeritve prostorskega razvoja poselitve in posameznih dejavnosti so v preteklosti zelo pomembno vplivale na obseg in stopnjo onesnaženosti okolja Ljubljane. Med gonilnimi 
silami, torej viri pritiskov na okolje MOL naj bi tudi v obdobju 2006-2015 zelo izstopal promet oziroma cestni promet, zlasti zaradi pozidave in obremenjevanja ozračja. Na drugem mestu pa naj bila poselitev (zlasti gospodinjstva oziroma stanovanja), predvsem pri pozidavi in onesnaževanju vodnih virov ter ustvarjanju odpadkov (Plut in drugi, 2006).

Število prebivalcev, gostota poselitve, povečevanje števila stanovanj oziroma območij bivanja so med drugim pomembno sovplivali na prostorsko širjenje in okoljske obremenitve v Ljubljani. Najbolj intenzivno je bilo prostorsko sirjenje po letu 1945. V obdobju po 2. svetovni vojni se je število prebivalstva in zaposlenih (več kot) podvojilo, poseljene površine pa so se povečale celo za 7-krat (Strategija trajnostnega razvoja..., 2001). Za Ljubljano je torej značilna velika poraba prostora na prebivalca, ki je posledica pozidave prostora za bivanje, zlasti pa za številne proizvodne dejavnosti ter storitve. Ekstenzivna raba urbanega prostora se kaže $\mathrm{v}$ večjih okoljskih pritiskov, kot jih bi pričakovali glede na število prebivalcev Ljubljane oziroma MOL. Vendar na celotnem območju MOL biva na površinah individualne stanovanjske gradnje tretjina prebivalcev, torej dve tretjini bivajo $\mathrm{v}$ večstanovanjskih hišah, zlasti v blokih. Skoraj polovica prebivalstva Ljubljane živi v blokovskih soseskah, zgrajenih po drugi svetovni vojni, najbolj pa se je gradnja blokov, večstanovanjskih hiš, razmahnila v 70. letih in prvi polovici 80. let 20. stoletja (Rebernik, 2000; 2002).

Ključni razlogekstenzivnega prostorskega razvojaMOLsštevilnimi okoljskonegativnimi posledicami je $\mathrm{v}$ zadnjih desetletjih obsežna, pretežno razpršena in pogosto nenadzorovana rast stanovanjskih in drugih pozidanih površin v predmestjih in primestnih območjih. Tako je po letu 1970 okoli Ljubljane nastal širok, okoli $25 \mathrm{~km}$ suburbanizirani pas, kjer živi velik del prebivalcev, ki se dnevno vozijo v Ljubljano. Zelo intenzivno je bilo zlasti širjenje proti jugu, torej na območje poplavnega in potresnega Ljubljanskega barja (Gašperič, 2005). Z načrtno (npr. Murgle, Trnovo) in v veliki meri z nenačrtno suburbanizacijo (npr. Rakova Jelša, Cesta dveh cesarjev, Sibirija) se je postopoma s pozidavami nižje gostote zapolnjevalo območje praviloma do južne avtoceste, južni del Ljubljane je tako postopoma izgubljal zvezdasto zasnovo. Tudi Dimitrovska Andrews in sodelavci (2001) med probleme tudi v razpoznavnosti mestne strukture izpostavljajo stihijsko pozidavo Barja oziroma južnega roba Ljubljane. Tako se v posameznih območjih zgoščuje nepremožno, etično heterogeno prebivalstvo na naravno ogroženih ali onesnaženih delih mesta, kjer so hkrati prisotni zelo pereči okoljski in socialni problemi (Krevs, 2002). V Sibiriji in Rakovi Jelši so prebivalci najbolj kritični do ožjega bivalnega okolja, saj jih je bilo več kot $57 \%$ nezadovoljnih s stanjem okolja, najbolj pa jih moti neurejena komunalna opremljenost (Špes in drugi, 2002). Vendar je potrebno poudariti, da je velika večina gradenj v navedenih območjih nastala brez potrebnih dovoljenj.

Obsežna nestrnjena suburbanizacijska pozidava skoraj celotne okolice Ljubljane zaseda veliko pretežno kmetijskega prostora, razmejuje in razparcelira pomembne biotope in habitatne tipe, zmanjšuje prezračevalne koridorje, hkrati pa zelo otežkoča odvajanje in čiščenje odpadnih voda, odvažanje komunalnih odpadkov. Večja oddaljenost od zadnjih postajališč mestnega in postajališč primestnega prometa ter železniških postaj dodatno zmanjšuje privlačnost uporabe mestnega in primestnega prometa in spodbuja vsakodnevni osebni motorizirani prevoz s številnimi okoljsko in energetsko negativnimi posledicami, vključno z velikimi emisijami toplogrednega ogljikovega dioksida. 
Ekspanzija oskrbno-storitvenih dejavnosti, ki je bolj ali manj prisotna na vsem sklenjeno pozidanem mestnem teritoriju in na njegovem obrobju, ustvarja izredno pestro rabo prostora celotnega mesta, njegovih posameznih delov in uličnih blokov. Stanovanjska funkcija še vedno prevladuje v srednjeveškem jedru Ljubljane, čeprav se iz njega po letu 1990 hitreje umika. To pa je odvisno od vrste vprašanj ekonomskega, lastniškega, prostorsko-funkcionalnega, pa tudi spomeniško-varstvenega značaja. Problemi so podobni kot v mestnih jedrih drugih evropskih mest, kažejo pa se v počasni prenovi, ki je v glavnem odvisna od ekonomskega položaja lastnikov in od investicijskega interesa (Pak, 2000). Tudi z okoljskega vidika je pomembna ugotovitev Paka (2002, s. 135) o trojni koncentraciji nestanovanjske rabe: v ožjem mestnem središču, ob glavnih prometnicah in v posameznih območjih mesta, hkrati z dokaj homogeno zgradbo na nekaterih drugih lokacijah, predvsem proizvodnih, izobraževalnih, zdravstvenih, upravnih in v zadnjem desetletju oskrbnih dejavnosti. Oskrbno-storitvene dejavnosti se vse bolj selijo v širše mestno središče, k glavnim prometnicam, po letu 1990 pa so se močno razmahnila raznovrstna oskrbna središča (Pak, 2000). Posamezni predeli mestnega obrobja postajajo zgostitve nestanovanjskih dejavnosti, ponekod združene v dokaj obsežne sklenjene komplekse.

Iz mestnega središča se stanovanjska funkcija še vedno umika, število in gostota prebivalstva pa se zmanjšujeta. S tem je prizadeta tudi oskrbna funkcija, ki jo med drugim odtegujejo nova oskrbna središča na mestnem obrobju. Nemalo prispeva k temu problematična dostopnost in pomanjkanje parkirišč (Pak, 2000). V tem pogledu izstopata vsaj dva primera: oskrbno središče Ledina, ki se vse bolj spreminja v administrativno-gostinski predel, in srednjeveško središče mesta, ker zlasti na njegovem obrobju trgovina nikakor ne more prav zaživeti. Ljubljana očitno tudi ne premore ustrezno strukturirane tradicionalne trgovske ceste v smislu glavne trgovske ceste, kakršne najdemo v vseh večjih evropskih mestih.

Funkcijska zgradba Ljubljane torej doživlja zlasti po letu 1990 nagel razvoj ter močne strukturne in prostorske spremembe. Kot državno središče prednjači v razvojnem pogledu in ob tem se krepi njena oskrbno-poslovna funkcija $v$ najširšem pomenu. V pogledu oskrbe ljubljanskega prebivalstva, delovnih mest in krepitve mestne ekonomije je to vsekakor pozitiven razvoj, v pogledu funkcionalne rabe mestnega prostora ter kvalitete življenjskega okolja pa nikakor ne (Pak, 2000, 2002).

Za MOL je značilna visoka in še vedno naraščajoča motorizacija, ki se kaže predvsem v trajnemu povečevanju motornih vozil. V obdobju 1985-2004 se je število motornih vozil povečalo od okoli 115000 na več kot 157 000, največji pa je delež osebnih vozil. Tako je bilo v letu 1990 v MOL nekaj več kot 100000 osebnih vozil, leta 2004 pa že več kot 130000 (Statistični letopis Ljubljane, 2005). V Ljubljani je že leta 1996 prišel en osebni avto na 2,5 prebivalca. Leta 2005 pa je bilo v MOL 159720 motornih vozil, od tega 132564 osebnih vozil (in okoli 10000 tovornih vozil), število prebivalcev na osebno vozilo pa je bilo 2,0 oziroma okoli 500 avtomobilov na 1000 prebivalcev (leta 1989=320) (Ljubljana, glavno mesto, 2006). V statistični Ljubljanski urbani regiji je leta 2002 živelo okoli 490000 prebivalcev, število osebnih avtomobilov pa je bilo konec leta 2004 okoli 240000 (Statistični letopis Ljubljane, 2005). V razliko s sodobnim upadom prebivalstva Ljubljane in MOL je za obdobje po letu 1990 torej značilno izrazito naraščanje lastništva avtomobilov, večje povprečno letno število prevoženih km na osebno vozila in večja dnevna migracija z avtomobili. 
Pojav drugega družinskega avtomobila (tudi tretjega) je skupaj s povečano uporabo avtomobila za vsakodnevne prevoze dodatno zaostril okoljske in prostorske probleme Ljubljane. Konec 90. let je bilo v Ljubljani le 28000 parkirnih mest, primanjkljaj pa se je hitro razširil iz mestnega središča, okolice $\mathrm{KC}$ in središča Bežigrada $\mathrm{v}$ subcentre in večje stanovanjske soseske (Prostorski plan MOL-Zasnove..., 2002). S postopnim zmanjševanjem energetskih, komunalnih in industrijskih emisij prihajajo vse bolj $v$ ospredje negativni vplivi prometnega onesnaževanja okolja. Narǎ̌čanje prometa $\mathrm{v}$ mestu ni opazno le po prometni gneči v samem mestnem jedru, ampak je predvsem očitno na mestnih vpadnicah in ljubljanski obvoznici (Špes in drugi, 2000). Mesto postaja zaradi stopnjevane motorizacije in skromne, zmanjšane privlačnosti javnega prevoza vedno bolj zasičeno s cestnim prometom.

Ob nadaljevanju trendov v 90. letih bi bilo potrebno do leta $2010 \mathrm{v}$ mestnem središču zgraditi več kot 11000 novih javnih parkirnih mest, kar je prostorsko in urbanistično nerealno pričakovanje.

Znotraj MOL vsak dan poteka približno 1,2 milijona potovanja z različnimi prometnimi sredstvi, kar 70\% teh potovanja opravijo namreč prebivalci Ljubljane, 30\% pa prebivalci regije (Verbič Miklič, 2004). Vsakodnevna potovanja prebivalcev iz regije v MOL predstavljajo torej okoli tretjino vseh potovanj oziroma prevozov. Podatki in ankete kažejo, da potovanja v šolo in na delo znotraj MOL pomenijo le tretjino prevozov, dve tretjini potovanja pa je nedelovnih (prosti čas, nakupi, osebni opravki itd.). V Ljubljanski urbani regiji je delež nedelovnih potovanj manjši, a še vedno znaša $61 \%$. Znotraj MOL se z avtomobilom na delo odpravi $66 \%$, v regiji pa kar $85 \%$, tudi za nedelovna potovanja se večinoma uporabljajo avtomobili, javni promet pa največ za pot $\mathrm{v}$ šolo. Po obsežni anketi iz leta 2003 naj bi se na območju MOL $58 \%$ vseh potovanj opravilo z avtomobilom, $19 \%$ peš, $10 \%$ s kolesom in le še $13 \%$ z javnim prometom. V Ljubljanski urbani regiji pa je bilo z osebnim avtomobilom opravljanih celo 73 $\%$ vseh potovanj, z javnim prometom pa zgolj 8 \% (Verbič Miklič, 2004). V Zuerichu pa je bilo npr. le $28 \%$ potovanj opravljenih z osebnim avtomobilom, z javnim prometom pa $37 \%$. V Freiburgu pa je na prvem mestu prevoz s kolesom (32\%), kateremu sledi javni promet $\mathrm{z}$ $21 \%$. V obeh mestih je mestna politika načrtno podpirala pospešeno rabo javnega prometa in nemotoriziranih prometnih sredstev, $\mathrm{v}$ Ljubljani pa je $\mathrm{v}$ zadnjih desetih letih poudarek nadgradnji nakupovalnih središč, razvoj dejavnosti zunaj tradicionalnih prometnih koridorjev, v ozadju pa razvoj mestnega središča in javnega prometa.

Pri tem velja poudariti, da je Ljubljana glede morfološke zgradbe izrazito neprimerna za potniški promet $\mathrm{z}$ osebnimi vozili. Zaradi značilne radialne krakaste oblike se potniški promet najbolj zgosti v mestnem središču. Dodatna težava je izrazita neuravnoteženost prometne razvitosti severnega in južnega dela mesta, saj je severni bistveno bolj obremenjen (Prostorski plan MOL-Zasnove..., 2002).

Znaraščanjem števila osebnih vozil in cenenim gorivom glede najavni prevoz se povečuje osebni, zmanjšuje pa javni potniški promet. Analize kažejo, da potniki, ki ne uporabljajo več javnega prometa, začnejo uporabljati osebne avtomobile. Posledica je večje onesnaževanje, naraščanje gneče ter prometnih zastojev $\mathrm{v}$ mestu ter povečanje pozidanih površin zaradi novih parkirnih prostorov in cest. V 90. letih so se razmere glede izbire prometnega sredstva $\mathrm{z}$ okoljevarstvenega in prostorskega vidika poslabšale. Rezervirane vozne pasove za avtobuse si v čedalje večji meri prilaščajo tudi drugi uporabniki. V središču mesta so zastoji v konicah 
avtobusom Mestnega potniškega prometa že znižali hitrost pod $10 \mathrm{~km} / \mathrm{h}$. S tem se podaljšuje čas potovanja in hkrati čakalna doba, to po dodatno odvrača potnike od uporabe avtobusov. Za enako frekvenco odhodov s postaj bi bilo potrebno več avtobusov, dohodek od prodaje vozovnic pa upada. Potovalni časi z avtobusi so za najmanj $30 \%$ daljši kot z osebnimi avtomobili. Večja raba osebnega vozila prinaša večje prometno okoljske pritiske. Posebej veliko je onesnaževanje $\mathrm{z}$ osebnimi vozili, ki se neogreta vključujejo $\mathrm{v}$ počasen promet $\mathrm{v}$ središču mesta. Pri tem niso izjema osebni avtomobili s katalizatorji, ki delujejo le, če so primerno ogreti. Zlasti v zimskem času začno katalizatorji delovati šele po nekaj km vožnje, vožnje pa so pogosto dolge manj kot pet km.

Po ocenah za leta 2000 naj bi vsakodnevno v Ljubljano pripotovalo okoli 110000 ljudi (Strategija trajnostnega razvoja..., 2001) oziroma 120000 ljudi, po drugi oceni pa 90000 120 000, od katerih jih dve tretjini uporablja osebno vozilo (Pichler Milanović, 2005-povzeto po Dekleva, 2000). Približno tretjino predstavljajo dnevni migranti na delo, desetina prihaja v šole, drugi pa zaradi nakupov in drugih opravkih (Dekleva, 1998). Zgolj pri potovanjih v šolo prevladuje delež prevoz z javnimi prevoznimi sredstvi, pri vseh ostalih oblikah vsakodnevnega potovanja pa osebni avtomobil. Visoka stopnja motorizacije in razpršena poselitev ključno vplivata na zmanjševanje potovanj zjavnimi in porast potovanj z zasebnimi prevozi. Intenzivna dnevna migracija povečuje uporabo cestne infrastrukture, zasedenost prostora zlasti v središču mesta, onesnaženost zraka, porabo energije in število prometnih nesreč (Dekleva, 1998).

V obdobju 1970-1990 je bilo v Ljubljani v cestno infrastrukturo vloženih kar $98 \%$ investicijskih sredstev, za infrastrukturo javnega prometa pa komaj $2 \%$. Potnik v osebnem avtomobilu je subvencioniran pri vsakem km vožnje z okoli 0,10 evra, potnik v javnem prometu pa z manj kot 0,02 evra (Strategija trajnostnega razvoja..., 2001). Leta 1970 je bilo $55 \%$ potovanj opravljenih z javnim prometom in 45 \% z osebnimi avtomobili. Leta 1994 je bilo $65 \%$ vseh dnevnih migrantov iz Ljubljanske urbane regije $\mathrm{v}$ MOL pripotovalo $\mathrm{z}$ osebnim avtomobilom in $35 \% \mathrm{z}$ javnim prometom (Dekleva, 1998). Konec 90 . let pa se je z javnim prometom opravilo $22 \%$, z zasebnimi prevoznimi sredstvi pa $78 \%$ vseh potovanj v Ljubljani (Prostorski plan MOL-Zasnove..., 2001). V kolikor se bodo trendi nadaljevali, potem bi leta 2020 že manj kot petina prebivalcev na ozemlju MOL vsakodnevno potovala $\mathrm{z}$ javnim prometom in več kot 80 \% z avtomobilom, kar je značilno za ameriška mesta (Preglednica 3). Zaradi poselitvenega in zaposlitvenega vzorca Slovenije je konec 90. let kar $90 \%$ vseh vsakodnevnih potovanj bilo opravljeno z osebnim avtomobilom (Prostorski plan MOL-Zasnove..., 2002).

Porast voženj z osebnimi vozili in zaostanek pri posodabljanju javnega prometa se odraža v stalnem upadanju števila pripeljanih potnikov v mestnem prometu, še bolj izrazit pa je padec števila prepeljanih potnikov v primestnem prometu. V letu 1986 je Ljubljanski potniški promet (avtobus) pripeljal 161 milijonov potnikov, leta 1999 pa le še 102,5 milijona. V letu 2005 je upadlo število prepeljanih potnikov z mestnim prometom na 90 milijonov (Ljubljana, glavno mesto, 2006). Leta 1986 je bilo z mestnim javnim prometom opravljenih okoli 350 000 potovanj na dan, leta 1998 pa le še okoli 176000 (Prostorski plan MOL-Zasnove..., 2001, 2002) (Preglednica 4). Kot kaže je bila v mestnem in primestnem javnem prometu konec 90. let dosežena najnižja možna vrednost. Brez korenitih posegov mestne politike v cestni urbani promet bo do leta 2020 število potnikov v javnem prometu ostalo na ravni konec 90 . let, avtomobilski promet pa bo še naprej naraščal. 
Preglednica 3: Napoved spremembe v izbiri prometnega sredstva v Ljubljani brez ukrepov (19702020)

Table 3: A prediction of the change in the selection of means of transport in Ljubljana without any measures

\begin{tabular}{|l|c|c|}
\hline Leto & $\begin{array}{c}\text { Javni } \\
\text { potniški } \\
\text { promet }\end{array}$ & Avtomobil \\
\hline 1970 & $55 \%$ & $45 \%$ \\
\hline 1977 & $50 \%$ & $50 \%$ \\
\hline 1994 & $34 \%$ & $66 \%$ \\
\hline 1998 & $22 \%$ & $78 \%$ \\
\hline 2020 & $17 \%$ & $83 \%$ \\
\hline
\end{tabular}

Vir: Dekleva, 1998; Prostorski plan MOL-Zasnove..., 2002

Preglednica 4: Število potovanj na dan v javnem potniškem prometu (1994-2020)

Table 4: The number of travels per day in public passenger traffic (1970-2020)

\begin{tabular}{|l|r|r|r|}
\hline Leto & Primestni promet & Mestni promet & Skupaj \\
\hline 1994 & 68500 & 138000 & 206500 \\
\hline 1998 & 37700 & 138000 & 175700 \\
\hline 2020 & 37700 & 138000 & 175700 \\
\hline
\end{tabular}

Vir: Prostorski plan MOL-Zasnove..., 2002

Povečano število potovanj $z$ osebnimi avtomobili se odraža tudi v večjih obremenitvah cestne mreže ter s tem povezanimi večjimi okoljskimi pritiski, zlasti večjo hrupnostjo. Promet na severni obvoznici se je v obdobju 1990-1999 podvojil (od 29000 vozil dnevno na 59 500), na zahodni obvoznici pa dosegel 70000 vozil dnevno (1. 1990-36 000).

V Ljubljani je s prometom najbolj obremenjeno mestno središče in območje od Bežigrada do Ježice ter Šiška, torej osrednji del mestne občine Ljubljana. V severnem, zahodnem in južnem delu ljubljanske občine ima sicer visoka prometna obremenitev predvsem linijski značaj (ob eni ali dveh večjih prometnicah). Njen vzhodni del je trenutno prometno še vedno najmanj obremenjen, a se povečuje po izgradnji vzhodne obvoznice. Hitrejše naraščanje prometnega obremenjevanja avtocestnih obvoznic je odziv na zasičenost mestnih ulic (Dekleva, 1998).

Ožje območje Ljubljane urbanistično ni prilagojeno avtomobilu kot množičnemu prometnemu sredstvu, vendar se tovrstni način prometa vse bolj uveljavlja. V Ljubljani bo moral visoko zmogljiv in kakovosten sistem mestnega javnega prometa (večje frekvence prevozov, hitrost potovanja, dostopnost, kakovost ponudbe) nase prevzeti tudi del obremenitev, ki jih bo zahtevala sanacija mirujočega prometa, saj parkiranje v mestnem središču zadnja leta predstavlja največji problem v prometni ureditvi mesta. Po izkušnjah in kriterijih, ki so jih pridobili v tujini, se kot dobro dostopna stanovanjska območja obravnavajo tista, ki so v krogu do $500 \mathrm{~m}$ od postajališča (Špes in drugi, 2000). 
Po podatkih iz leta 1996, ko je štela Mestna občina Ljubljana 269077 prebivalcev, je imelo kar 242913 njenih prebivalcev (90\%) zelo dober (do 500 metrov) dostop do postajališč mestnega potniškega prometa. Po dobri dostopnosti izstopa širše mestno središče, kjer živijo prav vsi prebivalci v 500-metrskem pasu do najbližjega postajališča mestnega potniškega prometa. Izven tega območja je dobra dostopnost do postajališč tudi ob mestnih vpadnicah in ob pomembnejših povezovalnih cestah, vmes pa je nekoliko slabša. V obmestnih naseljih praviloma nimajo urejenega mestnega prometa, temveč primestne avtobuse in lokalne vlake, kar še zlasti velja za vzhodni in južni periferni del občine (Špes in drugi, 2000).

Kljub zelo dobri dostopnosti do postajališč mestnega potniškega prometa je potrebno izpostaviti še dejansko funkcijo javnega prometa v Ljubljani, ki se v zadnjih letih izrazito zmanjšuje. Uporaba mestnega potniškega prometa ni odvisna le od njegove dostopnosti, ampak tudi od frekvence odhodov s postaj, hitrosti potovanja in kakovosti ponudbe. Kljub dejstvom, da avtobusi rabijo petkrat manj energije na potnika, manj onesnažujejo ozračje, manj obremenjujejo okolje s hrupom (vse z vidika števila prepeljanih potnikov) in so povrhu vsega še varnejši, je njihov pomen v vsakdanjem življenju prebivalcev Ljubljane vse manjši (z izjemo posameznih skupin prebivalcev - upokojenci, študenti, srednješolci).

V povprečju imajo Ljubljančani primerno dostopnost do postajališč mestnega potniškega prometa, manj ugodna pa je slika glede na potrebe po sodobnem in hitrem prevozu. V tem gre iskati tudi vzroke za neugodno miselnost in obnašanje prebivalcev, ki še vedno raje uporabijo lastno prevozno sredstvo in s tem dodatno prometno obremenjujejo mesto. Kljub akutnim problemom prometne zasičenosti se namreč število uporabnikov javnega mestnega prevoza $\mathrm{V}$ zadnjih letih zmanjšuje (Špes in drugi, 2000).

Dograditev ljubljanskih obvoznic in vzpostavitev cestnega obroča je sicer nekoliko sprostila tranzitne cestne pritiske, a prometne stiske mesta zaradi izredne letne stopnje naraščanja prevoza z osebnimi avtomobili v nasprotju z (pre)optimističnimi napovedmi ni odpravila. Ljubljanske obvoznice so zaradi svoje umeščenosti v mestno prometno tkivo dejansko postale organska sestavina (notranjega ) mestnega cestnega prometa, njihova tranzitna vloga je dejansko drugotna. S širšega prostorskega in prometnega vidika se ob nadaljevanju prometnih trendov torej ponovno odpira dilema (ne)upravičenosti enojnega sistema ljubljanskih obvoznic.

Cestni prometni pritiski v določenih dnevnih obdobjih dobesedno prometno paralizirajo posamezne mestne predele, kar povečuje porabo energije, časa, prometne emisije, hrupnost itd. Temeljni razlog za povečanje mestnega cestnega prometa je intenzivni notranji mestni avtomobilski promet, dnevna migracija in v manjši meri povečanje tranzitnega prometa. Tako tudi prometno zmanjšanje privlačnosti bivalnega okolja v središču mesta ter vse bolj omejene možnosti parkiranja avtomobila za stanovalce mestnega jedra dodatno vplivajo na večplastno negativni proces izseljevanja. Že sredi 90. let je v ožjem mestnem središču primanjkovalo okoli 5000 parkirnih mest, kar je bilo več od števila parkirnih mest v tem območju. Tudi pospešena gradnja garažnih hiš, posodobitev cestnega omrežja in strožji ukrepi dolgoročno ne morejo rešiti ključne prometne in okoljske težave Ljubljane, zlasti mestnega jedra.

Povečanje števila prebivalcev, relativno in primerjalno nizka cena osebnega avtomobilskega prevoza, prednostna gradnja cestnega omrežja, večja možnost zaposlitve in zgostitev različnih storitev v glavnem mestu ter povečanje razpršene poselitve v mestnem in gravitacijskem območju Ljubljane so ključni vzroki silovitega naraščanja motorizacije in osebnega moto- 
riziranega cestnega prometa $\mathrm{v}$ Ljubljani. Cestno prometni emisijski in prostorski pritiski so prostorsko-okoljska posledica navedenih prometnih trendov zlasti $\mathrm{v}$ zadnjih dvajsetih letih. Cestni promet je $v$ Ljubljani temeljni vir zračnih emisij in pritiskov na mestni prostor, saj je lata 2003 prispeval dve tretjini trdnih delcev, več kot polovico emisij $\mathrm{NO}_{\mathrm{X}}$ in tretjino emisij $\mathrm{CO}_{2}$ (Preglednica 53). V obdobju 1997-2003 so se zmanjšale emisije $\mathrm{NO}_{\mathrm{x}}$ (večji delež vozil s katalizatorji) in $\mathrm{SO}_{2}$, povečale pa emisije toplogrednega $\mathrm{CO}_{2}$.

Okoljska analiza in primerjava s stanjem sestavin okolja za obdobje 1990-2005 kaže, da naj bi v primeru udejanjanja zastavljenih usmeritev, ukrepov in projektov izdelanih Prostorskih zasnov Mestne občine Ljubljana (2002), kot strokovne osnove za nov prostorski plan, prišlo do leta 2015 v MOL na splošno do nekoliko večjega obsega prekomerne onesnaženosti, stopnja onesnaženosti pa naj bi bila v primerjavi s stanjem okoli leta 2004/2005 na splošno nižja. Med gonilnimi silami, torej viri pritiskov na okolje MOL naj bi tudi v obdobju 20062015 zelo izstopal promet oziroma cestni promet, zlasti zaradi novih pozidanih površin (ceste, parkirni prostori) in obremenjevanja ozračja. Zadnji podatki opozarjajo, da občasno dnevni promet na ljubljanski obvoznici doseže vrednost 100000 vozil, zaradi dnevne migracije (delo, šola, nakupi) pa je v Ljubljani več kot 150000 vozil (Prometno onesnaževanje ozračja...., 2006). V primeru nadaljnjega povečanja gostote prometa osebnih vozil, tranzitnega prometa (tovornjaki) in prometnega obremenjevanja se bo poslabšala kakovost bivalnega okolja in zmanjšala privlačnost MOL za investicije. Na drugem mestu po prihodnjih pritiskih na okolje pa naj bi bila poselitev (zlasti gospodinjstva oziroma stanovanja), predvsem pri onesnaževanju vodnih virov in ustvarjanju komunalnih odpadkov.

Morfološka zgradba mesta, Golovec in Šišenski hrib kot reliefna in zelena klina pogojujejo obseg strnjenega mestnega središča (notranji mestni obroč) in zvezdasto (krakasto) zasnovo s sedmimi pomembnimi mestnimi vpadnicami (Slika 3). Prostorska zasnova zato upravičeno poudarja krakasti razvoj mesta, širitev dejavnosti iz centra vzdolž nosilnih cest (javni potniški promet, zlasti linije mestne železnice) in a) lokalna zgostitev grajenega prostora med njimi ter hkrati b) med kraki varovati zelena pasova Tivoli z Rožnikom in Šišenskim hribom ter Gradu z Golovcem, zeleni pas ob Ljubljanici in vzpostaviti zelene kline (hkrati prezračevalni koridorji) iz zaledja proti mestnemu središču. Ohranjanje odprtih, nepozidanih, zelenih koridorjev, ki segajo iz obrobja proti mestnemu jedru, je nepogrešljivo za prevetrenost posameznih mestnih območij in dotok hladnejšega, svežega in čistega zraka $\mathrm{v}$ mesto z zračnimi emisijami. Predlaga se tudi celovito prevrednotenje odnosa do barjanskega dela MOL in čimprejšnja ustanovitev krajinskega parka. V MOL ni predvidenih lokacij za objekte toplotne obdelave odpadkov. Emisije škodljivih snovi v ozračje bi v kotlini povzročile nedovoljene obremenitve okolja.

Ključni problemi na področju prometa v Ljubljani so povezani z vztrajno rastjo števila in rabe osebnih vozil ter hkrati s premalo učinkovitim delovanjem javnega prometa. Temeljni cilj je zmanjšati rabo avtomobila in izboljšati javni prevoz. Javni promet naj bi temeljil na novi mestni železnici (tramvaju), krakasta oblika mestnega tkiva je zelo primerna za uvedbo tirnega sistema javnega prometa (Slika 4). Sedanji sistem javnega potniškega prometa (JPP) na regionalni ravni ne omogoča hitre dostopnosti. Prihodnji prometni sistem naj bi bil učinkovit, družbeno sprejemljiv in zasnovan okoljevarstveno primerno. Krakasta oblika grajenega mestnega tkiva je zelo primerna za zmogljivo, učinkovito in privlačno delovanje 
Slika 3: Prostorska zasnova - morfološka zgradba Ljubljane

Figure 3: A spatial scheme - the morphologic structure of Ljubljana

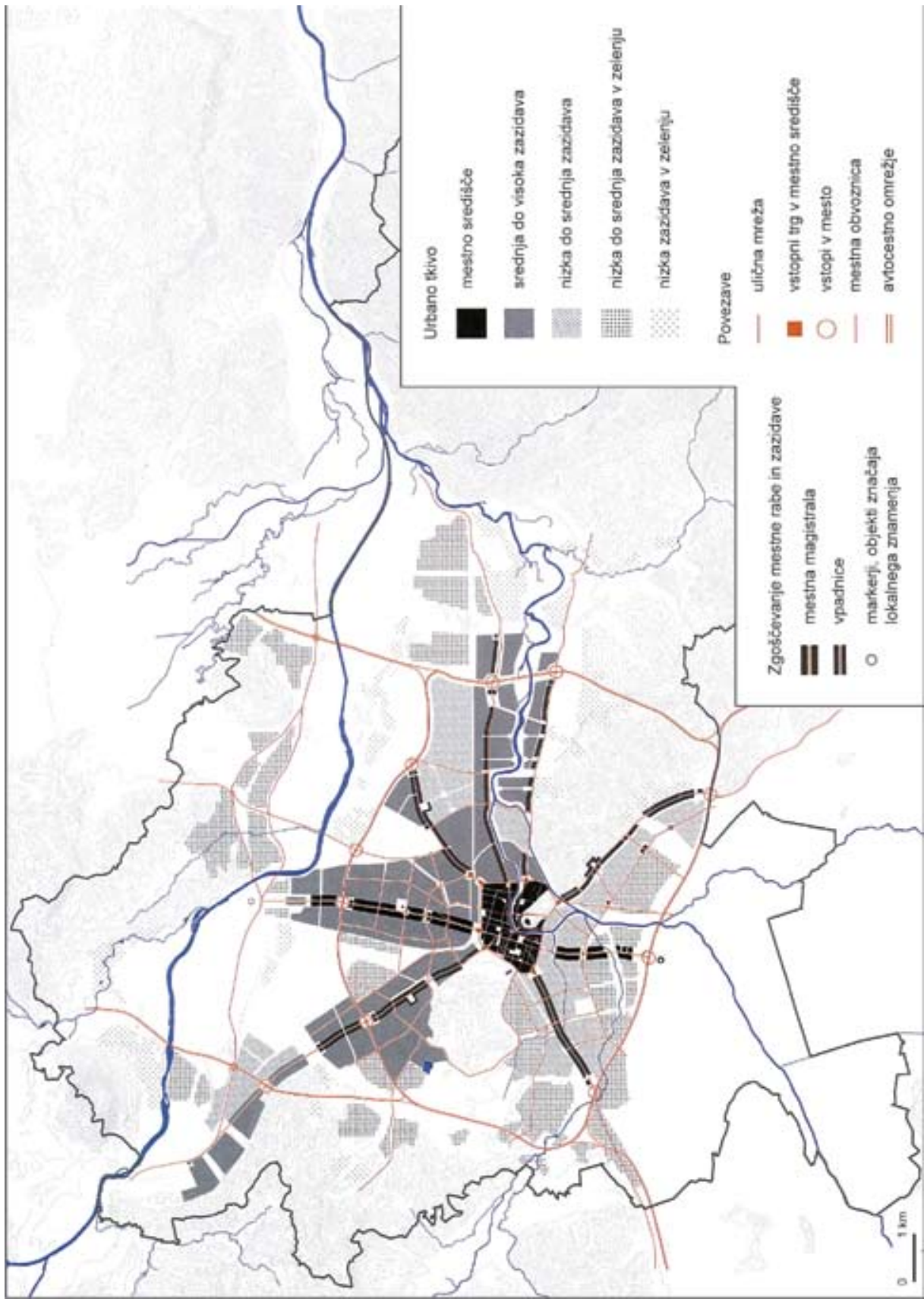


Slika 4: Prostorska zasnova - javni potniški promet MO Ljubljana

Figure 4: A spatial scheme - public passenger traffic of the Municipality of Ljubljana

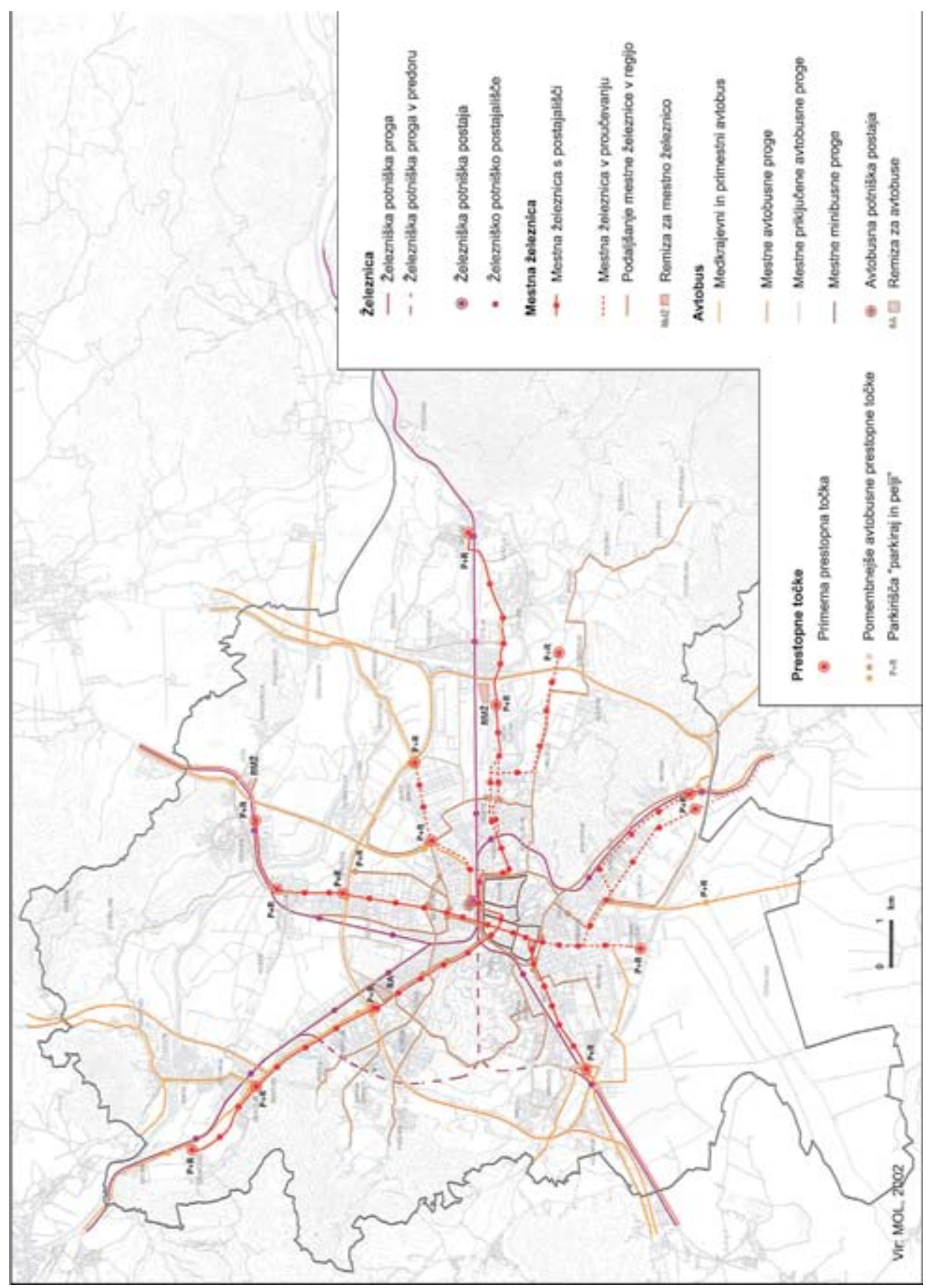


sistema tirnega javnega prometa. Uvedba tirnega javnega prometa omogoča krepitev razvojnih možnosti mestnega središča in nadgradnjo radialno krakaste urbanistične zgradbe mesta. Primarni nosilec potniškega prometa morajo postati sredstva JJP, $v$ regionalnem merilu pa zlasti regionalna železnica, ki naj bi v rednih in pogostejših voznih taktih povezovala Ljubljano z drugimi urbanimi središči in naselji v regiji (Prostorska zasnova, 2002). Prednostna, finančno zelo zahtevna razvojna in prostorsko-okoljska strateška naloga Ljubljanske urbane regije, MOL in mesta Ljubljane je sodobna izboljšava sistema mestnega in regionalnega javnega potniškega prometa (železniškega, avtobusnega, tramvajskega). To mora postati prednostni projekt Ljubljane, regije in tudi države. Vzpostavitev trajnostne mobilnosti Ljubljane je okoljski predpogoj za uspešno vsestransko delovanje in oblikovanje mestne in regionalne zgradbe ter razvoj gospodarskih in drugih dejavnosti v njej.

Poleg mestnega središča je uvedba mestne železnice upravičena na urbanih zgostitvah razvojnih krakov, predvsem na štirih vpadnicah: na Dunajski, Celovški, Zaloški in Tržaški cesti. Proučuje se tudi upravičenost poteka po Šmartinski, Litijski in Barjanski cesti ter po Jurčkovi poti ali alternativno po dolenjski železniški progi. Mestno železnico je možno v nekaterih krakih podaljšati v regijo, najrealnejše so možnosti proti Domžalam in Kamniku ter Grosupljem, kjer bi uporabili in nadgradili (zdajšnje) železniške proge. V prvi etapi naj bi bila zgrajena mestna železnica na odseku Tržaška cesta-Dunajska cesta z remizo v Črnučah, v drugi pa Stanežiče-Moste do središča Polja). Vsi kraki se naj bi združili v mestnem središču, kjer sta dve inačici: po prvi poteka mestna železnica tudi v mestnem središču na površju (nivojska), po drugi pa podzemno.

Predvidena Prostorska zasnova MOL pa bi z nekaterimi projekti nove pozidave dejansko zlasti v severnem delu mesta zmanjšala manevrski prostor učinkovitih, dovolj širokih in sklenjenih prezračevalnih koridorjev, hkrati pa se povečuje pozidava kmetijskih zemljišč in vodnoekološka občutljivost vodooskrbno ključnega Ljubljanskega polja. Ohranjanje in izboljšanje kakovosti Ljubljanskega polja je brez dvoma eden od ključnih strateških varovalnorazvojnih ciljev Ljubljane, sonaravna pokrajinska raba v vodovarstvenih pasovih, ohranjanje nepozidanega prostora in zmanjševanje emisijskega vpliva na talno vodo Ljubljanskega polja pa ena od osrednjih sonaravnih ciljev prostorske politike. Razvoj poselitve v obmestnem prostoru bo torej potrebno okrepljeno usmerjati v obstoječa zgostitvena območja ob predvidenih trasah tirnega mestnega prometa. Zavirati in preprečevati po potrebno razpršeno gradnjo ter sanirati urbane degradirane površine $v$ razvojne in tudi zelene javne površine, ki jih v številnih območjih mestnega središča in posameznih blokovskih soseskah že sedaj zelo primanjkuje. Območja varstva vodnih virov so namenjena ohranjanju količine in kakovosti podtalnice Ljubljanskega polja, ki zadovoljuje okoli $90 \%$ potreb Ljubljane po pitni vodi. Najpomembnejši ukrep varstva vodnih virov je opredelitev varstvenih pasov in sicer najožjega (1.), ožjega (2.) in širšega (3.) z različnimi režimi varovanja. Glede na nove strokovne ugotovitve bo potrebna sprememba meja varstvenih pasov in režimov. Ljubljana leži v pretežni meri na območju varovanja vodnih virov, kar zahteva vodnoekološko pretehtane posege v prostor.

Osrednji kanalizacijski sistem odvaja odpadno vodo iz pretežnega dela Ljubljane in dela občine Medvode. Z dopolnitvami sistema je potrebno zagotoviti odvajanje in čiščenje odpadnih vod iz celotne MOL ter delov občin Brezovica, Medvode, Vodice in Škofljica. $\mathrm{V}$ skladu z usmeritvami varovanja vodnih virov je treba prioritetno zagotoviti odvajanje 
odpadnih voda na območju v ožjem (2.) varstvenem pasu vodnih virov, nato pa na območjih v širšem varstvenem pasu. Tako je potrebno kanalizacijo najprej zgraditi na območjih starih Stožic, črnuške Ježe, poseljenih območij Hrastja in deloma Sneberij, ker ležijo na območju ožjega varstvenega pasu vodnih virov. S kanalizacijo je treba opremiti tudi vsa neopremljena območja v dosegu osrednjega kanalizacijskega sistema (Rakova Jelša, Sibirija, Rudnik, Ižanska cesta, Črna vas, Dolnice, Glince, Tacen, Šentjakob, Polje, Hrušica, Polje, Novo Polje, Zadvor, Sostro, Sadinja vas, Podmolnik) je treba kanalizirati. Vse objekte, ki so znotraj območja osrednjega kanalizacijskega sistema, je treba priključiti na omrežje kanalizacije in odvesti na osrednjo čistilno napravo Zalog.

Trajnostno sonaravni (okoljski, ekonomski in socialni) prostorski razvoj Ljubljane in MOL kot celote naj bi izhajal iz osnovnega principa okoljske stranice, ki poudarja sonaravno zahtevnejši princip prostorskega razvoja: prostorska razmestitev in raba prostora naj bo v okviru zmogljivosti okolja in njegovih sestavin na ozemlju MOL. Okoljska analiza in presoja (stanje, trendi in posledice degradacije temeljnih sestavin okolja) prostorskega razvoja MOL (s poudarkom na Ljubljani) za obdobje 1990-2005 namreč kaže, da so okoljski urbani pritiski poselitve in številnih dejavnosti pogosto presegali omejene samočistilne zmogljivosti. Izjemo predstavljajo zlasti območja vzhodnega višjega, redkeje poseljenega, podeželskega obrobja. Kljub temu podatki kažejo, da je mogoče s premišljenimi kurativnimi in preventivnimi ukrepi doseči visoko kakovost bivalnega okolja in življenja, kar bi Ljubljani omogočilo, da postane kakovost življenja njena konkurenčna prednost glede na druga srednjeevropska mesta.

Za prihodnji sonaravni prostorski razvoj MOL je torej ključno zmanjševanje številnih okoljskih pritiskov (okoljska bremena) s pomočjo kurativnih in preventivnih ukrepov. Med preventivnimi ukrepi je s prostorskega vidika v ospredju okoljevarstveno in naravovarstveno optimalno prostorsko (geografsko) razporejanje poselitve in dejavnosti v skladu $\mathrm{z}$ omejeno zmogljivostjo okolja in naravnih virov.

Za ozemlje MOL udejanjanje navedenega sonaravnega principa pomeni, da je $v$ ospredju (Plut in drugi, 2006):

1. ohranjanje okoljsko izredno ugodne zvezdaste zasnove mesta in zelenih klinov, kar omogoča na eni strani sonaravno optimalno organizacijo javnega prometa in na drugi strani visoko kakovost bivalnega okolja, kakovost sonaravnega urbanega življenja in primerne površine bioproduktivnega in rekreacijskega odprtega prostora;

2. uravnoteženje gostote pozidave in drugih ključnih okoljskih pritiskov med bolj obremenjeno severno in manj obremenjeno južno polovico širšega mestnega prostora Ljubljane;

3. ohranjanje in z varovalnimi ukrepi povečanje prepotrebnih samočistilnih zmogljivosti, pokrajinske in biotske pestrosti mestnega in podeželskega ekosistema MOL;

4. postopno zmanjševanje visoke porabe naravnih virov in proizvedenih različnih emisij na prebivalca MOL (vključno s potrebo po zmanjševanju toplogrednih emisij na prebivalca) tudi s primerno prostorsko organizacijo območij bivanja, dela in prostočasnih dejavnosti kot pomembnega globalnega cilja Slovenije in Evropske zveze.

Z globalnega okoljskega vidika je v obdobju 2006-2015 tudi za MOL ključna naloga zmanjšanje emisij toplogrednih plinov, ki posredno pozitivno vpliva tudi na zmanjšanje 
lokalnih okoljskih pritiskov. V teoriji in praksi so preventivne usmeritve in ukrepi prostorske politike ključni za zmanjševanje snovno-energetskih tokov in s tem povezano zmanjševanja zlasti emisij toplogrednega $\mathrm{CO}_{2}$. Vendar v Prostorskih zasnovah tako med cilji usmerjanja prostorskega razvoj MOL, kot pri prostorskih zasnovah po področjih navedeno globalno (posredno tudi regionalno in tudi lokalno) sonaravno izhodišče načrtovanja prostorskega ni posebej navedeni kriterij prostorskega razmeščanja dejavnosti. Dejstvo pa je, da nekateri navedeni cilji (npr. zgoščevanje mesta, prestrukturiranje prometa, večja mešana raba prostora) in načrtovani razvoj po področjih (npr. mestna železnica, širjenje daljinskega ogrevanja) omogočajo $\mathrm{v}$ posameznih primerih zmanjševanje emisij toplogrednih plinov in $\mathrm{s}$ tem povezano smotrnejšo rabo naravnih virov. Delna izjema je področje energetike, kjer je med cilji na področju energetike navedeno tudi varovanje okolja (izpolnjevanje mednarodnih obveznosti, zmanjšanje emisij $\mathrm{CO}_{2}$, uporaba ekološko ustreznejših goriv, priključevanje na sistem daljinskega ogrevanja). Vendar je hkrati predvidena gradnja enega ali dveh postrojenj toplarne, ob možnemu zmanjšanju porabe premoga bistveno večja raba zemeljskega plina, med cilji energetsko in toplogredno intenzivnega prometa pa ni cilja zmanjševanja ali vsaj stabilizacije emisij $\mathrm{CO}_{2}$ do leta 2015 (zgolj »zmanjšanje negativnih vplivov prometa na okolje«). Pri konkretnih ciljih na področju cestnega prometa pa so le cilji boljšega delovanja cestnega prometa, okoljski oziroma emisijski (lokalni, regionalni ali globalni) pa prav tako niso omenjeni, kar velja tudi za prostorske (npr. smotrnejša raba prometnih prostorov ali stabilizacija cestnoprometnih površin).

Glede na dejstvo, da cilj $8 \%$ zmanjševanja emisij toplogrednih plinov do leta 2012 glede na emisije v izhodiščnem letu (1986) v Prostorskih zasnovah (2002) ni posebej izpostavljen in zaradi več kot 20 \% povečanja emisij toplogrednega $\mathrm{CO}_{2}$ v obdobju 1986-2012 v MOL sodimo, da je nujna dopolnitev usmerjanja prostorskega razvoja na način, ki bo pomembno sovplival na možnost (glede na bistveno poslabšanje izhodiščnega položaja zlasti v obdobju 1990-2004) vsaj približevanje navedenemu, zelo zahtevnemu cilju. V kolikor pa ne bo prišlo do pomembnega zasuka $\mathrm{v}$ proizvodnji in rabi energije, načinu prevoza in drugih način proizvodnje toplogrednih emisij, potem do leta 2012 v MOL ne bo dosežene niti stabilizacija emisij toplogrednih plinov glede na izhodiščno leto 1986, možno pa je celo povečanje v obdobju 2006-2012 (2015). MOL pa naj med drugim predpiše strožje kriterije toplotne zaščite stavb (zlasti pri novih gradnjah) in tudi metode za vrednotenje rabe energije in pritiskov na okolje v življenjskem obdobju stavb. V splošnem so ukrepi za zmanjšanje ekoloških sledi (odtisov) mobilnosti povezani z naslednjimi, splošno znanimi ukrepi (Plut in drugi, 2006):

- $\quad$ izboljšanje infrastrukture za kolesarjenje in pešačenje;

- $\quad$ povečanje uporabe javnega prometa;

- $\quad$ povečanje uporabe goriv proizvedenih iz obnovljivih virov energije;

- določitev ločenih cestnih linij za vozila z nadpovprečnim številom potnikov;

- $\quad$ vzpodbujanje souporabe osebnih vozil in koles;

- $\quad$ zmanjšanje površine, ki je namenjena osebnim vozilom.

Ekološke sledi javnega prevoza z avtobusi v Ljubljani glede na prepeljane potnike znatno presegajo vrednosti določene v primerljivih študijah za druga mesta. Zmanjšanje ekoloških sledi bi zagotovili med drugim $\mathrm{z}$ uporabo plinastih fosilnih goriv in integralnim pristopom. 
Ponovno opozarjamo na večplastno okoljsko neprimerno množično premeščenje številnih mestnih dejavnosti in zaposlitve v primestna območja. Tako so v Kobenhavnu ugotovili, da je premestitev poslovnih centrov v predmestja povzročila večjo uporabo osebnih vozil uslužbencev, saj se je delež teh zvišal iz četrtine na več kot polovico. Ravno tako so ugotovili, da uslužbenci uporabljajo osebna vozila 10 do $15 \%$ bolj pogosto, če so pisarne oddaljene od postajališč javnega prometa za več kot $500 \mathrm{~m}$. Prav tako moramo upoštevati, da prebivalci evropskih mest le 20 do $30 \%$ prevozov opravijo za dostop do delovnega mesta. Precej večje prevožene razdalje so posledica bodisi dejavnosti v prostem času ali nakupovanj, kar je potrebno bolj upoštevati pri prostorskem razmeščanju dejavnosti in poteka prog javnega prometa v MOL. Skupaj z drugimi primernimi ukrepi mestne politike je možno doseči cilj, da bi 20-30 \% (namesto sedanjih slabih $10 \%$ ) potovanj v Ljubljani bilo opravljeno z okolju prijaznim kolesom. Glede na primerno morfologijo mesta, relativno ugodno podnebje ( $v$ primerjavi s kolesarskimi skandinavskimi državami), skromno reliefno energijo (majhni strmci kolesarskih prog) ima kolesarjenje v MOL objektivno vse pogoje, da postane do leta 2015 druga (po javnem prevozu-mestna železnica) najbolj pogosta, okolju (tudi z vidika zmanjševanja toplogrednih plinov) in zdravju najbolj prijazna oblika vsakodnevnega potovanja prebivalcev mesta (zlasti v razdaljah med 1-5 (10) km).

Morfološka zgradba mesta, Golovec in Šišenski hrib kot reliefna in zelena klina pogojujejo obseg strnjenega mestnega središča (notranji mestni obroč) in zvezdasto (krakasto) zasnovo s sedmimi pomembnimi mestnimi vpadnicami. Prostorska zasnova zato upravičeno poudarja krakasti razvoj mesta, širitev dejavnosti iz centra vzdolž nosilnih cest (javni potniški promet, zlasti linije mestne železnice) in a) lokalna zgostitev grajenega prostora med njimi ter hkrati b) med kraki varovati zelena pasova Tivoli z Rožnikom in Šišenskim hribom ter Gradu z Golovcem, zeleni pas ob Ljubljanici in vzpostaviti zelene kline (hkrati prezračevalni koridorji) iz zaledja proti mestnemu središču. Predvidena Prostorska zasnova MOL pa z nekaterimi projekti nove pozidave dejansko zlasti v severnem delu mesta zmanjšuje manevrski prostor učinkovitih, dovolj širokih in sklenjenih prezračevalnih koridorjev, hkrati pa se povečuje pozidava kmetijskih zemljišč in vodnoekološka občutljivost vodooskrbno ključnega Ljubljanskega polja. Razvoj poselitve v obmestnem prostoru bo torej potrebno okrepljeno usmerjati v zgostitvena območja ob predvidenih trasah tirnega mestnega prometa, zavirati in preprečevati razpršeno gradnjo ter sanirati urbane degradirane površine v razvojne in tudi zelene javne površine, ki jih v številnih območjih mestnega središča in posameznih blokovskih soseskah že sedaj zelo primanjkuje. Sodimo, da je upoštevanje klimatsko pomembnih območij in nujnost ohranjanja prezračevalnih koridorjev iz obrobja v mestno središča za kotlinsko Ljubljano pomembna sonaravna usmeritev (Plut in drugi, 2006).

Tudi za Ljubljano velja, da je varstvo okolja eno izmed treh temeljnih (gospodarsko in socialno polje), a neenakovredno obravnavanih polj sonaravnega (trajnostnega) mestnega razvoja. Čeprav se Ljubljana med evropskimi mesti podobne velikosti ne uvršča med najbolj degradirana urbana območja, predstavljajo okoljski problemi zaradi številnih posledic na kakovost bivanja in izčrpavanje naravnih virov, ogrožanja narave, enega od ključnih problemov Ljubljane in celotne MOL. Prostorsko razmeščanje prebivalstva in dejavnosti v pokrajinsko zelo različno občutljivih območjih MOLje eden od ključnih razlogov razširjenosti in intenzivnosti okoljsko degradacijskih procesov. Z vidika sonaravnega razvoja je sedanja 
kakovost ljubljanskega geografskega okolja razvojna ovira, vendar praviloma ne gre za nepovratne pojave degradacije okolja oziroma njegovih sestavin.

V sedanjem razvojnem in civilizacijsko vrednostnem trenutku ti. šibke sonaravnosti (trajnostnosti) je tudi v MOL še nerealno razmišljanje o zahtevi radikalnega okoljskega prostora o zamrznitvi kakršnekoli nove pozidave na območju MOL, čeprav se število prebivalcev po vsej verjetnosti tudi do leta 2015 ne bo povečalo. V tem okviru je potrebno torej z vidika uvajanja principov šibke sonaravnosti ocenjevati nekatere dodatne konkretne predloge, ki seveda glede na okvirne cilje s prednostno okoljskega vidika opozarjajo na okoljsko vprašljivost nekaterih novih posegov v občutljivo okolje in prostor MOL-a ter predlagajo alokacije, ki pa seveda niso okoljsko neoporečne, a okoljsko večplastno bolj primerne od načrtovanih v Prostorski zasnovi (2002).

Ključni, okoljsko zasnovani dodatni predlogi za izdelavo Prostorskega plana MOL so naslednji (Plut in drugi, 2006):

- $\quad$ predlagamo, da se globalni cilj zmanjševanja emisij toplogrednih plinov (in $s$ tem povezanega ekološkega odtisa, sledi) navede kot cilj usmerjanja prostorskega razvoja MOL in temu primerno upošteva pri prostroskemu razvoju;

- $\quad$ predlagamo sprejetje odločitve o čimprejšnjem začetku gradnje mestne železnice in dograditvijo ključnih prog do leta 2012 in dejansko dosledno uporabo sonaravnega kriterija 5-minutne hoje oziroma 400 m oddaljenosti od postajališča načrtovane mestne železnice (javnega prometa) in ohranjanje prezračevalnih koridorjev od obrobja proti središču mesta kot ključna kriterija pri gradnjah obsežnejših poselitvenih ter razvojnih območij;

- $\quad$ predlagamo pospešitev sprejetja odločitve o lokaciji regionalnega odlagališča odpadkov $s$ tem povezanega (ne)odlaganja odpadkov na odlagališču Barje (po letu 2009) (glede na obstoječe podatke je odlagališče Barje kljub nekaterim okoljskim problemom najbolj primerna lokacija) ter posebne prostorske ukrepe za odpravo nedovoljenega odlaganja odpadkov;

- $\quad$ namesto načrtovanega prekomernega povečanja okoljskih pritiskov (zlasti pozidave) $v$ že močno antropogeniziranem in občutlijvem severnem delu urbanega ekosistema Ljubljane (Ljubljansko polje) predlagamo, da se pretehta predlog okoljsko manj sporne, nekoliko večje strnjene, pasovne urbanizacije (antropogenizacije) že degradiranega območja Barja ob podaljšku Barjanske ceste (mestna železnica);

- $\quad$ predlagamo prostorsko bolj ambiciozno, a sonaravno pretehtano gradnjo na širšem območju novega Potniškega centra Ljubljane in celovito oceno možne delne premestitve nekaterih načrtovanih mestotvornih (športnih, rekreacijskih, razstaviščnih, morda tudi univerzitetnih itd.) iz severnega v južno obrobje Ljubljane, v podaljšek Barjanske ceste (»Center Barje«); z okoljevarstvenega in naravovarstvenega vidika ter naravne ogroženosti (poplavnost), mestotvornega kriterija je možna lokacija islamskega verskega središča ob Parmovi primernejša od lokacije ob Cesti dveh cesarjev;predlagamo, da mesto spodbuja razvoj razvejane mreže lokalnih mestnih središč srečevanja in nakupov, trgovska in druga storitvena in bivalna (stanovanjska) vloga mestnega središča ter omeji nadaljnjo gradnjo velikih primestnih trgovskih centrov (zgolj s potrebno, oskrbno nujno zaokrožitvijo ponudbe); 
Slika 5: Okoljsko sporni projekti prostorskih zasnov MO Ljubljana (2002)

Figure 5: Environmentally disputable projects of the Spatial schemes of the Municipality of Ljubljana (2002)

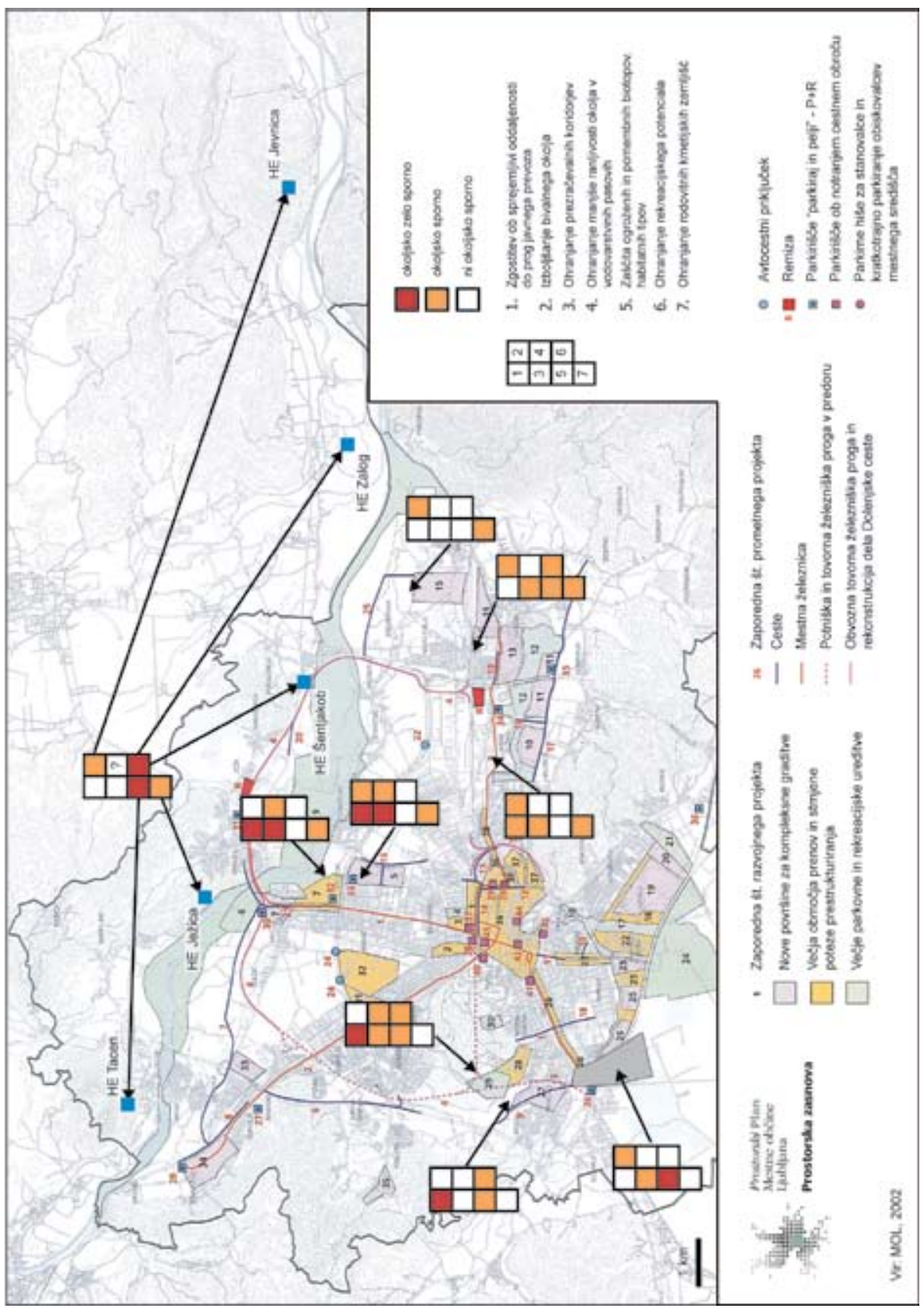


- $\quad$ predlagamo zmanjšanje primanjkljaja javnih parkovnih površin v nekaterih blokovskih stanovanjskih soseskah in odločne ukrepe tudiprostorske politike za ureditevproblematike vrtičkarstva, ki so vse bolj pereč okoljski in pejsažni problem;

- $\quad$ predlagamo, da se še večja pozornost nameni pospešeni gradnji sistema kolesarskih cest, saj naj bi kolesarjenje postalo po pomenu druga (po javnemu prevozu) najbolj razširjena oblika vsakodnevnega urbanega potovanja do leta 2015;

- $\quad$ predlagamo večplastno, razvojno-varovalno preverjanje lokacij okoljevarstveno in naravovarstveno spornih projektov Prostorskih zasnov (2002) (Slika 5): Univerzitetno središče pod Rožnikom, Tehnološki park Brdo (zaradi gradnje je mogoča le smotrna omejitev širjenja), Športno središče Stožice, Univerzitetno središče ob Vojkovi in savske HE. Predlagamo, da se ob enakovrednem soočenju okoljskih posledic z ekonomskimi in socialnimi $v$ največji možni meri a) s spremembami v mikrolokaciji ali okoljsko pretehtani gradnji zmanjšajo njihovi pritiski na okolje in naravo, b) upošteva nujnost ohranjanja samočistilnih sposobnosti (npr. zračnih preduhov, vlažnih ekosistemov, c) upošteva možnost uporabe javnega prometa in v posameznih primerih za nekatere predlagane razvojne projekte poišče drugo, okoljsko primernejšo lokacijo.

Z okoljskega vidika pa je potrebno pozitivno podčrtati načrtovana območja spremembe namembnosti v degradiranih urbanih območjih (območje Elme v Črnučah, proizvodna območja v Tacnu in Gameljnah in del območja komunalne cone v Spodnjih Poljanah).

Ob predlaganih dopolnilih z vidika varstva okolja in narave je po našem mnenju izdelana Prostorska zasnova MOL z okoljskega vidika primerna strokovna zasnova za načrtovanje okolju in naravi bolj prilagojenega prostorskega razvoja. Zmanjšanje sedanjih prekomernih pritiskov plinskih emisij, hrupa, odpadnih vod, odpadkov je sonaravni pogoj nadaljnjemu prostorskemu načrtovanju in zmogljivostim okolja prilagojenemu razmeščanju mestnih dejavnosti v MOL. Mestne politike, zlasti urbanistična in prometna, naj bi zmogljivostim urbanega okolja prilagojenemu načrtovanju dejavnosti Ljubljane v prihodnje namenile večjo pozornost.

\section{Literatura}

Dekleva J., 1998. Predlog za ustanovitev projektnega sveta za razvoj javnega potniškega prometa v regiji in mestu Ljubljana. Oddelek za urbanizem in okolje MOL, Ljubljana.

Dimitrovska Andrews K., 2000. Procesi urbanizacije v Sloveniji in posledice na urbana omrežja. Urbani izziv 11/1, s. 3-15.

Environment in the European Union at the Turn of the Century, 1999. Office for Official Publications of the European Communities, Copenhagen.

Kladnik D., Rejec Brancelj I., Smrekar A., 2005. Kmetijsko obremenjevanje. Podtalnica Ljubljanskega polja. Geografija Slovenije 10, Založba ZRC, s. 134-163.

Mušič V., 1999. Ljubljana, Mesta in urbanizacija. Svet za varstvo okolja RS, Ljubljana, s. 52-54.

Pak M., 2000. Funkcijska zgradba. Ljubljana-geografija mesta, LGD, Založba ZRC, Ljubljana, s. 53-58. 
Pak M., 2002. Funkcijska zgradba Ljubljane. Geografija Ljubljane, Oddelek za geografijo FF, Ljubljana, s. 131-149.

Pichler Milanović N., 2005. Ljubljana: From "Beloved" City of the Nation to Central European "Capital", Transformation of Cities in Central and Eastern Europe: Towards Globalization, United Nations University Press, s. 318-363.

Plut D., 2000. Okoljevarstvene razsežnosti (ne)sonaravnega prostorskega razvoja Ljubljane. Ljubljana-geografija mesta, LGD, Založba ZRC, Ljubljana, s. 155-162.

Plut D., 2002. Vodni viri Ljubljane kot razvojni in omejevalni dejavnik. Geografija Ljubljane, Oddelek za geografijo Filozofska fakulteta, Ljubljana, s. 21-50.

Plut D., Lampič B., Šarec A., Pichler Milanović N., Medved S., 2006. Okoljska analiza in presoja prostorskega razvoja Mestne občine Ljubljana v obdobju 1990-2015 (raziskovalna naloga). Oddelek za geografijo, Filozofska fakulteta.

Prometno onesnaževanje ozračja v Ljubljani znotraj AC obroča, 2006. Oddelek za geografijo, Filozofska fakulteta.

Prostorski plan Mestne občine Ljubljana-zasnova prostorskega razvoja (gradivo za razpravo), 2001. MOL-Oddelek za urbanizem, Ljubljana.

Prostorski plan Mestne občine Ljubljana-prostorska zasnova, 2002. MOL-Oddelek za urbanizem, Ljubljana.

Rebernik D., 2000. Morfološka zgradba. Ljubljana-geografija mesta, LGD, Založba ZRC, Ljubljana. s. 39-52.

Rebernik D., 2002. Socialnogeografska zgradba in preobrazba Ljubljane. Geografija Ljubljane, Oddelek za geografijo, Filozofska fakulteta, Ljubljana, s. 83-114.

Statistični letopis Ljubljane, 2005. MOL-Center za informatiko, Služba za mestno statistiko in analize, Ljubljana.

Strategija trajnostnega razvoja mesta Ljubljana-predlog strategije, 2001. Oddelek za urbanizem in okolje Mestne občine Ljubljana, Ljubljana.

Špes M., Lampič B., Smrekar A.A., 2000. Kvaliteta bivalnega okolja v Ljubljani, Ljubljanageografija mesta, LGD, Založba ZRC, Ljubljana, s. 163-174.

Špes M., Cigale D., Lampič B., 2002. Izstopajoči okoljski problemi v Ljubljani. Geografija Ljubljane, Oddelek za geografijo, Filozofska fakultata, Ljubljana, s. 51-82.

Verbič Miklič Š., 2004. Prestolnica avtomobilov-izsledki raziskave potovalnih navad Ljubljančank in Ljubljančanov, Glasilo MOL 2004/5-6, Ljubljana, s. 28-30.

Trajnostni razvoj Mestne občine Ljubljana-strategija, 2002. Oddelek za urbanizem MOL, Ljubljana.

Plut, D., 2005. Teoretična in vsebinska zasnova trajnostno sonaravnega napredka. V: Geografski pogledi na regionalni razvoj. Ljubljana, Filozofska fakulteta, Oddelek za geografijo (Dela, 23, str. 59-113).

Poročilo o razvoju. 2002. Murn, A., Kmet, R. (ur.). Ljubljana, Urad RS za makroekonomske analize in razvoj.

Radej, B., 1999. Razvoj indikatorjev za vrednotenje okoljske kakovosti gospodarske rasti. Delovni zvezek, 7, 10, Urad RS za makroekonomske analize in razvoj.

Seljak, J., 2000. Merjenje uravnoteženega razvoja: doktorska disertacija. Ljubljana, Ekonomska fakulteta. 
Seljak, J., 2001. Kazalec uravnoteženega razvoja. Ljubljana, Urad za makroekonomske analize in razvoj.

Vester, F., 1991. Kriza prenaseljenih območij. O razvijanju ekosistemskega mišljenja. Ljubljana, DZS.

Vintar, K., 2003. Okoljevarstveni vidiki sonaravnega regionalnega razvoja Slovenije: magistrsko delo. Ljubljana, Filozofska fakulteta, Oddelek za geografijo.

Vrišer, I., 1992. Uvod v geografijo. Ljubljana, Filozofska fakulteta, Oddelek za geografijo.

\section{SUSTAINABLE DIRECTIVES OF FUTURE SPATIAL DEVELOPMENT OF LJUBLJANA}

\section{Summary}

In the municipality of Ljubljana (MOL) environment, protection presents one of the basic but not equivalently dealt with fields of sustainaable urban development. Although Ljubljana among other European cities of a similar size is not ranged amongst the most degraded urban regions, environmental problems present one of the key problems. The basin position, poor ventilation and eco-systemic significance of the Ljubljana Barje, the water supplying regional role of Ljubljana Polje's underground water, the larger relief energy of MOL's Eastern margin, seismism and floods are the basic natural limitations of Ljubljana space development and its limited self-cleaning capabilities. The smaller self-cleaning capabilities of Ljubljana basin's Southern part and relatively large burdening of landscape-forming components of the very sensitive Ljubljana Polje fundamentally affect the big vulnerability of Ljubljana geographical surrounding and the MOL as a whole. The morphological town structure, Golovec and Šiška hills as relief and green wedges condition the range of the condense town centre (inner town circle) and star-like (shank-like) scheme with seven important city inroads. The space scheme (2002) therefore righteously stresses the shank-like development of the city, the widening of activities from the centre along the supporting roads (public transport, especially the city railway routes) and a) a local condensing of the built space between them and at the same time b) protecting the green zones between shanks; Tivoli with Rožnik and Šišenski hill as well as Ljubljana castle with Golovec, the green zone by the river Ljubljanica and restore the green wedges (air corridors at the same time) from the hinterland to the city centre.

The envisaged realisation of the Space scheme is that MOL would, with some projects of new masonry, actually reduce, the manouvering space, especially in the Northern part of town, of effective, sufficiently wide and connected airing coridors, at the same time the building of farmland and water-ecological sensitiveness water-supplying key Ljubljana Polje is intensifying. Preserving and ameliorating the quality of Ljubljana Polje is no doubt one of the key strategic protective-development goals of Ljubljana, co-natural landscape usage in water-protecting zones, preservation of unconstructed space and the reduction of emission ascendance of Ljubljana Polje underground water should be one of central co-natural goals of the space policy. The development of settling in the environs zone will have to be strongly directed into already existing condensed areas by envisaged zones of railway town traffic. 
The dispersed construction will have to be checked and prevented and improvement of the degraded urban areas into developmental as well as green public areas that are currently lacking in numerous regions in the town centre and in separate apartment building neighbourhoods will have to be made.

The protection of Ljubljana Polje underground water, preservation of eco-systematic services of Ljubljana Barje, preserving the airing corridors from the outskirts to the town centre, calming down suburbanising processes and road traffic are the basic co-natural challenges of Ljubljana town policies. The survey of some accessible environmental pointers of Ljubljana development underlines some positive measures of reducing polluting the town air (gas supply system and long-distance heating) and arrears in solving environmental traffic problems and partly also in dealing with waste waters and in managing municipal waste, all of them being basic environmental curative tasks until the year 2015. The key preventive co-natural area-urbanizing duty of future period is adjusted into the arranging of settling and activities that are adjusted to the environment and nature. The preferential, financially very demanding developmental and area-environmental strategic duty of Ljubljana urban region MOL and the City of Ljubljana is an up-to-date improvement of the town and regional system of public transport (railway, bus, and tram). A). this has to become the preferential project of the Ljubljana region and the state. Restoration of permanent mobility in Ljubljana is the environmental prerequisite for successful universal functioning and forming of town and regional construction and development of economic and other activities in it.

For MOL, territory realisation of mentioned sustainable principle denotes that in forefront there is:

1. preserving the environmentally extremely favourable star-like devised town and green wedges which enables, on the one hand sustainable optimal organisation of public transport and on the other hand a high quality of sojourn environment, the quality of co-natural urban life and suitable areas bio-productive and recreational open space;

2. balancing the density of building and other key environmental pressures between the more burdened North and less burdened South half of the greater Ljubljana town area;

3. $\quad$ preserving and with preservation measures enlarging the much needed self-cleaning capacities, landscape and bio-diversity of town and provincial ecosystem of MOL;

4. gradually reducing high usage of natural resources and produced different emissions per inhabitant MOL (including the need for decreasing greenhouse emissions per inhabitant) also with suitable space organisation of living areas, work and free time activities as Slovenia's and European Union's important global goal.

From the global environmental point of view, the key task in the period from 2006 to 2015 also for MOL is the reduction of emissions of greenhouse emissions that affect the reduction of local environmental pressures.

In theory and in practice the preventive directives and measures of space politics are the basis for reducing substantial-energetic streams and in connection with this the reduction especially of emissions of $\mathrm{CO}_{2}$. We suggest multi-layer, development-protective verification of locations of environmental protective and nature protective disputable projects of space plans: The University centre under Rožnik, Technological park Brdo (owing to building, only 
a proper limitation of spreading is possible), Sport centre Stožice, University centre on Vojkova street and Savske power station. We suggest that at an equivalent degree of confrontation of environmental consequences with economic and social consequences to the greatest possible degree a) reduce their pressures on the environment and nature, b) consider the necessity of preserving self-cleaning capabilities (e.g. airshaft, moist ecosystems, c) consider the possibility of using public transport and d) in separate cases find a different, environmentally more suitable location.

In the present development and civilisation, of the 'weak sustainability' (lastingness) it is also unrealistic at MOL to think about the demand of radical environmental space, about freezing any kind of new building in the MOL region although the number of inhabitants will probably not increase until 2015. In this timeframe it is therefore necessary from the point of view of introducing the principles of weak sustainability to evaluate some additional concrete suggestions which according to frame goals from the preferential environmental view point out the environmental questionableness of some new interventions into delicate environment and MOL space and suggest allocations which of course are not environmentally faultless but environmentally more suitable than the ones planned in the Space plan (2002).

The results of environmental analyses and judgement of carrying into effect the projects of the Space plan (2002) show that the intensity of environmentally degrading processes should lessen while the extent of the excessive burdening of the environment should somewhat expand, especially due to the traffic and increasing construction. Despite this we believe that in comparison with the period 1990-2005 the MOL Space plan for the period 2006-2015 is a suitable step in the direction of co-natural paradigm and is according to the leading directions as a whole sustainable suitable and in general, considering suggested completions, it enables (and by other measures of communal and regional as well as state politics) the realisation of elementary co-natural, environmental principles of space development in Ljubljana and the entire MOL. 
